\title{
Synergies of Learning Analytics and Learning Design: A Systematic Review of Student Outcomes
}

\author{
Marion Blumenstein ${ }^{1}$
}

\begin{abstract}
The field of learning analytics (LA) has seen a gradual shift from purely data-driven approaches to more holistic views of improving student learning outcomes through data-informed learning design (LD). Despite the growing potential of LA in higher education (HE), the benefits are not yet convincing to the practitioner, in particular aspects of aligning LA data with LD toward desired learning outcomes. This review presents a systematic evaluation of effect sizes reported in 38 key studies in pursuit of effective LA approaches to measuring student learning gain for the enhancement of HE pedagogy and delivery. Large positive effects on student outcomes were found in LDs that fostered socio-collaborative and independent learning skills. Recent trends in personalization of learner feedback identified a need for the integration of student-idiosyncratic factors to improve the student experience and academic outcomes. Finally, key findings are developed into a new three-level framework, the LA Learning Gain Design (LALGD) model, to align meaningful data capture with pedagogical intentions and their learning outcomes. Suitable for various settings - face to face, blended, or fully online - the model contributes to data-informed learning and teaching pedagogies in $\mathrm{HE}$.
\end{abstract}

\section{Notes for Practice}

- The systematic analysis of learning activities and their effects on students' behavioural and academic engagement revealed that student-idiosyncratic learning analytics data have an important role in analytics-informed learning designs.

- Large gains can be attributed to collaborative learning, as well as learning and teaching approaches where students have the opportunity to reflect on their progress and are provided with scaffolds to support time management, self-efficacy, and online presence.

- Caution must be exercised when interpreting effect sizes reported in educational research because the impact on student outcomes and learning gains relies on contextual factors, as well as the actions of the teacher.

- It is important to discuss and understand the potential of learning analytics - informed personalization for the benefit of students' well-being and relatedness rather than focusing on performance measures alone.

\section{Keywords}

Analytics framework, collaborative learning, effect size, higher education, learning analytics, learning design, learning gain, personalized learning, online learning, self-regulation, student learning

Submitted: 03/01/20 - Accepted: 25/10/20 — Published: 17/12/20

Corresponding author ${ }^{1}$ Email: m.blumenstein@auckland.ac.nz Address: Faculty of Science, The University of Auckland, 23 Symonds Street, Auckland 1142, New Zealand, ORCID ID: https://orcid.org/0000-0002-1769-5588

\section{Introduction}

The field of learning analytics (LA) is influenced by analytic methods and data capture and handling practices from a range of fields, including computer science, social sciences, and educational psychology, employing various mathematical models, algorithms, and processes (Cooper, 2012; Papamitsiou \& Economides, 2014). LA can be defined as the "... measurement, collection, analysis and reporting of data about learners and their contexts, for purposes of understanding learning and the environments in which it occurs" (Conole, Gašević, Long, \& Siemens, 2011). In recent years, the LA literature has seen a shift from its early conceptual papers and review articles that established common ground (Dawson, Gašević, Siemens, \& Joksimović, 2014) to more applied LA research via technology mediation of learning in order to optimize student engagement and outcomes in the context of relevant theories (e.g., Reimann, 2016) and learning design (LD) frameworks (e.g., Lockyer, 
Heathcote, \& Dawson, 2013; Bakharia et al., 2016). However, transferring LA research into the higher education (HE) classroom, whether face to face, blended, or fully online, can be problematic for practitioners (Gašević, Dawson, \& Siemens, 2015; Gunn et al., 2017). Therefore, the aim of the present study is to disentangle the complex interrelationships between LA (the data) and LD (the environment) within various teaching and learning contexts and provide a new framework to guide HE educators in their design decision-making processes to enable meaningful data capture for desired learning gains.

LD as a methodology enables practitioners to make pedagogically informed decisions about how activities and resources prompt optimal learning in diverse contexts (Gašević, Dawson, Rogers, \& Gašević, 2016; Rienties, Toetenel, \& Bryan, 2015). From an increasing awareness of the close connection between LA data and pedagogic theories and practice (Gašević, Dawson, \& Siemens, 2015; Mor, Ferguson, \& Wasson, 2015) have emerged several conceptual frameworks that can facilitate and support analytics-informed teaching practices. Some researchers focus on institutional implementation (Rienties et al., 2016); others on the evaluation of LD pedagogy and LA (Lockyer et al., 2013) and teacher inquiry (Bakharia et al., 2016). Therefore, LA will be of little practical value if isolated from a careful analysis of the teaching context and pedagogical intent.

\subsection{The Current Research}

The present systematic review responds to the need for further research into the opportunities and benefits of LA for dataenabled designs for wider adoption in HE (e.g., Bakharia et al., 2016; Rienties et al., 2016). Recent meta-analyses offer some insight into more effective LA-LD alignments, focusing on student retention and academic success (Sønderlund, Hughes, \& Smith, 2018), the current state of LA-based interventions in HE (Ferguson \& Clow, 2017; Viberg, Hatakka, Bälter, \& Mavroudi, 2018), and an LA-LD taxonomy (Mangaroska \& Giannakos, 2019). Navigating the vast LA evidence base is problematic for practitioners who centre design decisions on empirically validated and commonly accepted principles and theories of learning and teaching. Moreover, "the overall potential of LA is [still] so far higher than the actual evidence" (Viberg et al., 2018, p. 108), and much work still needs to be done to overcome the widespread unease about adoption (Ferguson, Clow, Griffiths, \& Brasher, 2019).

As Alhadad, Thompson, Knight, Lewis, and Lodge (2018) argue, LA needs to move its focus away from "end-state outcomes" (p. 429) toward designs for student learning and teaching practice. However, education systems are continuously evaluated in terms of student outcome and value of investment, where student achievement needs to be measurable in some way. Learning is complex, combining different dissections of academic and behavioural performance (e.g., Reschly \& Christenson, 2012), and no single proxy for measuring student outcomes exists (e.g., Joksimović et al., 2018). Embedding learning gain approaches into the curriculum for the meaningful measurement of student outcomes as proposed by Evans, Kandiko Howson, and Forsythe (2018) is an appealing concept for the purpose of informing effective practice within teaching contexts. Moreover, the use of "big data" and LA in learning gain approaches has the potential to obtain actionable insight on students' learning processes and trajectories to support enhancements to HE practice (Evans et al., 2018). In doing so, the emphasis is shifted from data to pedagogy for the informed use of LA that can support student learning.

The present systematic analysis of effect sizes of instructional approaches explores the potential of LA to offer insight into learning gains: what worked, for whom, and why. It contributes to the ongoing LA-LD debate and proposes a new model of the integration of LA data with LD and learning gain. Following Evans et al.'s (2018) premise that learning gain approaches in HE should be integral to curriculum design and delivery, the primary purpose of the present study is to provide evidence of data-informed teaching and learning effectiveness within specific contexts to stimulate the dialogue between teachers, learning designers, and curriculum managers. Two existing frameworks provided the necessary dimensions for the development of an integrated data-to-design-to-student-outcome model. The "Future of Learning" framework (Redecker et al., 2011) places collaboration, informalization, and personalization at the centre of strategies that shape the future of education in response to the needs and challenges of today's learners. It is well aligned with current issues and common goals in the HE sector globally, which increasingly calls for the use of data to improve student outcomes in employability, equitable access, lifelong learning, and digital literacy. The "Learning Gains in HE" model (Vermunt, Ilie, \& Vignoles, 2018) provides robust conceptions of cognitive, metacognitive, socio-communicative, and affective learning that have been validated across students' subjectspecific and non-subject-specific knowledge, skills, and attitudes. This classification aided the mapping of LD effects on students' cognitive and behavioural learning processes reported in the primary studies, answering a call for the inclusion of richer LA data (e.g., Tempelaar, Rienties, Mittelmeier, \& Nguyen, 2018) to inform more nuanced teacher actions.

Three research questions (RQs) guided the systematic analysis in two phases: first, to extract and synthesize the evidence presented in selected studies covering the years 2011 to 2016 for the development of a new model that integrates LA with LD for improved student outcomes, and, second, to evaluate the new model (literature spanning 2016 to 2019) and provide evidence-based linkages between LA data types and sources, and LD and intended outcomes, as follows:

RQ1: What kinds of LA are examined in relation to student learning outcomes utilizing collaborative, independent, and personalized learning approaches?

RQ2: Can LA effectively guide LD to optimize cognitive, metacognitive, socio-collaborative, and affective processes with 
the goal of an integrated model of data-informed learning gain?

RQ3: What is the evidence that an integrated model of data-informed learning gain developed in RQ2 can be effectively employed to inform LD decisions to improve student outcomes?

Given the focus on practice, only studies that proposed instructional approaches as an integral part of the design were included, excluding research on data mining, modelling, and proof of algorithmic principles.

\section{Methods}

To ensure rigour and minimize researcher bias, the present study follows Kitchenham and Charters's (2007) guidelines for performing systematic reviews in software engineering, which closely align with the interdisciplinary nature of LA research.

\subsection{Selection Criteria and Search Procedures}

\subsubsection{Electronic Literature Search}

A comprehensive online database search for the extant literature was conducted in two phases, as illustrated in Figure 1. Phase One covered the years 2011 until March 2016 (steps 1 to 3) and formed the basis for the development of an integrated LA Learning Gain Design (LALGD) model (RQ1 and RQ2). The year 2011 was chosen as the starting point because it coincided with an agreed definition of the term learning analytics (Conole et al., 2011). Phase Two searches (April 2016 until end of 2019 in step 4) provided the key studies for evaluation of the newly proposed model. The following search terms were applied:

First-order search: The title, abstract, and/or keywords must contain at least one of the terms learning analytics OR academic analytics $\mathrm{OR}$ educational data mining OR learning analytics data AND

Second-order search: The title, abstract, and/or keywords must contain at least one of the terms quantitative OR statistic OR correlation OR regression OR machine learning OR predict AND

Third-order search (Phase Two only): The title, abstract, and/or keywords must contain the terms learning AND analytics AND design (OR instruction).

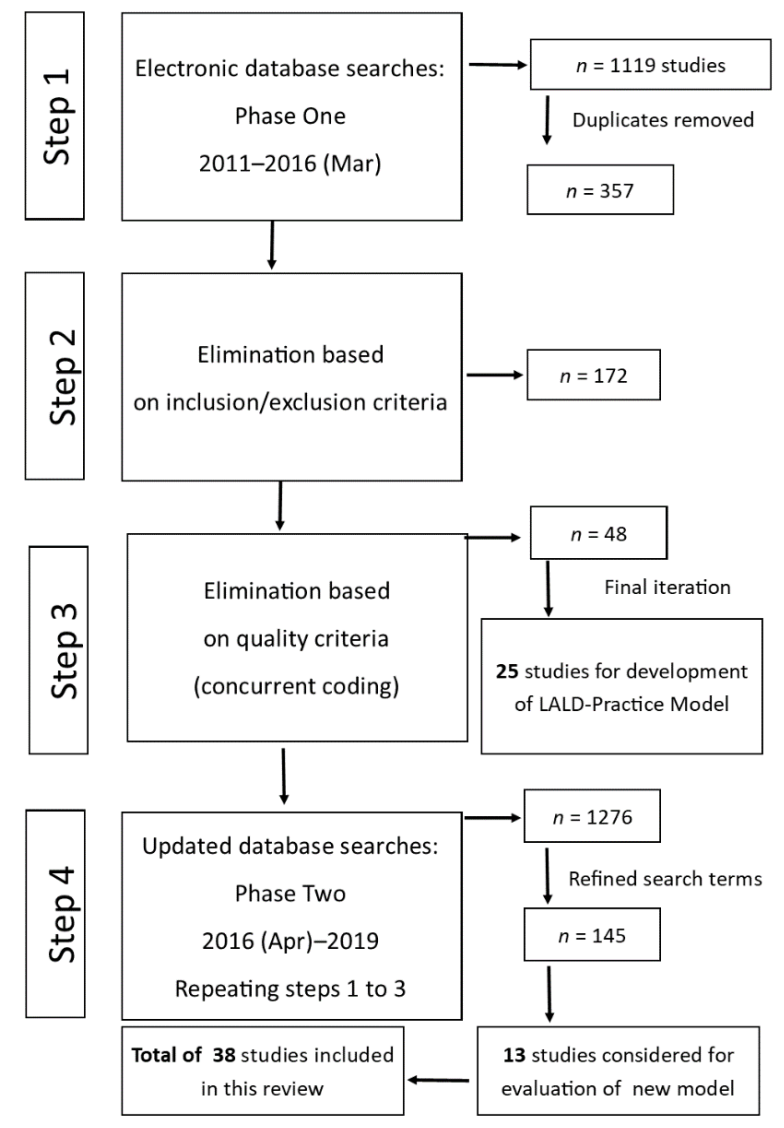

Figure 1. Summary of the systematic review process

The terms in the second-order search were based on commonly used statistical techniques in LA research (Papamitsiou \& Economides, 2014) in anticipation of revealing measures of effect size (RQ2). For the updated search in Phase Two (step 4), 
search terms were refined to reveal studies where the link between LA and LD was made explicit by including the terms design and learning and analytic. Differences in database search functionality required the delimitation of outputs from ACM and GoogleScholar, which produced results in the thousands. Therefore, search strings were adapted to machine learning AND (academic analytics OR learning analytics OR educational data mining). Subsequent searches simply replaced the first term with either quantitative, statistic, correlation, regression, or predict. GoogleScholar searches were not included in Phase Two of this review due to a threefold increase in overall LA publications since 2016, many with little relevance to the posed RQs. Database filters were applied to all searches in steps 1 to 4 to reveal studies that

1. were published in English,

2. were published in peer-reviewed journals/conference proceedings,

3. were published between January 2011 and December 2019,

4. were a case study or technical report, and

5. relied on students as participants (LIMIT-TO students).

\subsubsection{Inclusion and Exclusion Criteria}

After the elimination of duplicates in EndNote X8 and applying the inclusion/exclusion criteria outlined below, 172 studies were retained and prepared for coding to answer RQ1 and RQ2, and 145 academic papers were selected for the retrospective evaluation of the newly developed model (RQ3). In a second step, the titles, abstracts, and publication format were scanned for relevance. Qualitative and purely descriptive studies, books, editorials (e.g., Ifenthaler et al., 2014), conference abstracts (not proceedings), and theoretical papers were excluded. To reduce selection bias, technical reports and case studies were included if data procedures were adequately presented (e.g., Milliron, Malcolm, \& Kil, 2014), whereas scoping studies were eliminated (e.g., Gašević, Kovanović, Joksimović, \& Siemens, 2014). Studies about massive open online courses (MOOCs) were included if they covered academic subject content and showed practical significance for HE (e.g., Adamopoulos, 2013). Participants were students enrolled in postsecondary education, that is, undergraduate and postgraduate programs at tertiary/university level worldwide.

\subsubsection{Quality Assessment, Data Extraction, and Coding}

First, studies that met the initial inclusion criteria $(n=172$ for 2011-2016; $n=145$ for 2016-2019) were assessed based on Kitchenham and Charters (2007, pp. 25-27). Evaluative questions (see Table S1 in Appendix A - Supplementary Material) were designed collaboratively by the author and two LA experts (coders), paying attention to the following factors:

- Research design: The aims had to be clearly stated and variables fully defined and adequately measured to answer the $\mathrm{RQ}(\mathrm{s})$.

- Conduct: The data collection procedures were explained, biases/confounders addressed, and dropouts or exclusions explained.

- Analysis: Variables, data, sampling and analysis methods, and effects were appropriately described.

- Conclusion: The RQ(s) were answered, and implications for LA practice and LD discussed (i.e., the LA-LD link was made explicit).

Second, to answer RQ1 and RQ2 (Phase One) and develop a new LA-LD model that integrates learning outcomes, comprehensive descriptions of each study and a rationale for elimination were collated into a sharable data extraction form based on Kitchenham and Charters (2007, pp. 30-31; see Supplementary Table S2). The author worked collaboratively with the coders in an online document, which allowed us to examine each other's criteria for inclusion of a paper in the current review. Through an iterative process of checking the information in the sheet against the criteria, 48 out of 172 studies remained (see step 3, Figure 1). Another 23 studies were excluded, in particular those that focused solely on algorithmic modelling of LA data (e.g., Calvert, 2014; Huang, Huang, \& Chuang, 2016), resulting in a final set of 25 papers (see Supplementary Table S3 for details). Specifically, the included studies

- focused on learning outcomes revealed by LA collected with pedagogical intent,

- emphasized the role of instruction and design to identify learning variables,

- reported effects on learning outcomes using statistical techniques rather than descriptive analysis to query the data, and

- provided a section on the practical significance of findings and/or recommendations for practice.

Third, to answer RQ3 (Phase Two), 13 studies resulting from the updated search (2016-2019) that met the quality criteria in steps 2 and 3 (Figure 1) were deductively coded against the three categories outlined in Section 2.2.1 below: collaboration, independent learners, and personalization. Details of each study, regarding context, sample size, effects on learning outcomes, and implications for LD, are summarized in Supplementary Table S4.

\subsection{Categorization Scheme}

The selected studies were categorized in two ways: first, thematically according to three perspectives adapted from Redecker 
et al. (2011; see Supplementary Figure S1 for the original framework), and, second, according to effects on learning across four components in light of Vermunt et al.'s (2018) framework of learning gains in HE.

\subsubsection{Future of Learning Framework}

Three broad themes were developed: (1) collaboration, (2) independent learners, and (3) personalization. Specifically, the selected studies were categorized as follows:

- Collaboration - social learning and collective efficacy: These studies utilized collaborative tools such as asynchronous discussions, social networks, and peer learning in groups to foster collaboration and social presence.

- Independent learners - self-regulation and real-life learning: These studies investigated students' skills of selfregulating, managing time, and developing awareness of learning as a process, as well as the effect of authentic learning on outcomes.

- Personalization - tailored learning and predictive analytics: In these studies, personalized feedback was provided to students to support learning persistence, engagement, self-regulation, and cognition.

Originally, Redecker et al. (2011) coined the second category (here independent learners) as informalization-lifewide learning and learning skills for lack of a more appropriate term at the time (see note, p. 44). This perspective acknowledged the importance of reflection and authentic and holistic learning to lifelong learning. To better suit the HE context, the term was replaced for the current review with independent learners.

\subsubsection{Effects on Learning Gains}

To critically examine which LA-informed designs and approaches were most effective for improving student outcomes related to RQ2 - can LA effectively guide LD to optimize cognitive, metacognitive, socio-collaborative, and affective processes with the goal of an integrated model of data-informed learning gain? - effect sizes reported in the primary studies were recalculated as Cohen's $d$ (Cohen, 2013). To capture both subject- and non-subject-specific student learning, extracted effect sizes were categorized according to learning gains across four components (Vermunt et al., 2018, pp. 274-275):

1. cognitive, such as reasoning abilities and critical and analytical thinking;

2. metacognitive, for example, self-regulation, learning to learn, information seeking, monitoring and modifying attitudes and behaviours toward certain learning goals;

3. affective, such as attitudes toward learning, motivation, social and emotional engagement, academic interest;

4. socio-communicative, for example, belonging in social learning networks, social embeddedness, communication skills.

To aid the interpretation of instructional approaches to student learning outcomes reported in the key studies, effects were broadly categorized into learning performance (defined as grades, exam marks, scores, final mark, GPA), course outcome (pass/fail, completion, re-enrollment), and online presence (cognitive presence, cognitive learning, online behaviour changes); see Supplementary Table S3 for details. Email nudges and infographics directed at students were categorized as affective because nudging requires consideration of engagement pedagogy (Baker, 2010) and students' connectedness to the learning environment (Pardo et al., 2018).

\subsection{Recalculating Effect Sizes}

A statistician prepared a document for each study, extracting the main hypotheses and correlation coefficients $\left(r, R^{2}\right)$, regression coefficients $(b)$, Hedges' $g$, and model precision indicators (e.g., odds ratio) for transformation into Pearson correlation coefficient $r$ as well as Cohen's $d$ according to Rosenthal and DiMatteo (2001). Where effect sizes were not reported, confidence intervals, standard errors, $F$ ratios, and $t$ ratios were used (Rosenthal \& DiMatteo, 2001). The author checked and re-checked the tables provided by the statistician against the original studies to ensure correct representation of findings for the subsequent meta-analysis. The focus of the present review is on the impacts of LD on learning outcomes as seen through an LA lens, which can be either positive or negative. To ease interpretation of the results, this study focused on reporting main effects (not interactions), which were predominantly positive, corroborating previous findings that negative effects are often underreported in the education literature due to publication bias (Cheung \& Slavin, 2016). If several main effects were reported in a study, then the negative effects were only included when one instructional method (or learning intervention) was shown to be less effective than another (see Supplementary Table S3).

To answer RQ2 and simplify complex interrelationships between instructional variables and learning outcomes, effect sizes were classified into no to small (Cohen's $0<d<0.35)$, medium $(0.35<d<0.66)$, and large $(>0.66)$ based on achievement correlates in HE proposed by Schneider and Preckel (2017). Sample sizes of the selected studies were grouped into small (up to 100 students), medium (100-250), and large (more than 250) based on Cheung and Slavin's (2016) findings that effect sizes can be influenced by sample size as well as research design. Effect sizes from selected studies identified in the updated search (RQ3) were recalculated into Cohen's $d$ (see Supplementary Table S4), where appropriate, using online freeware available at www.psychometrica.de. 


\subsection{Limitations}

While the database searches were conducted in a systematic way according to robust criteria characteristic of systematic reviews, a manual search was not undertaken, potentially biasing the selection process. However, new research published in the field is contained in the ACM Digital Library, including relevant conferences such as LAK and IEEE. Limitations to the search query may not have captured important research in the fields of design and instruction because the searches were conducted in the context of LA. The author and two coders identified suitable papers for the model development (Phase One) using a sharable form for consistency of applying inclusion/exclusion criteria. A lack of interrater reliability may pose a risk to the unbiased selection, particularly in Phase Two, where coders were not part of the data collection process.

Due to the inconsistency of reported effects in the key papers, common coefficients (Cohen's $d$ and $r$ ) were calculated, which may threaten the generalizability due to student factors as well as variation in contexts (e.g., Schneider \& Preckel, 2017). However, Cohen's $d$ is commonly used for comparison purposes in meta-analyses and can guide the reader toward the main messages contained in the data. Extracted effect sizes were categorized qualitatively into four perspectives of learning gains (Vermunt et al., 2018), which may add a level of subjectivity. Furthermore, the inconsistency and lack of an overarching definition for student learning outcome resulted in a broad categorization of effects on learning performance, course outcome, and online presence, which may be invalid as a general definition of outcome. The intention was to aid the interpretation of results based on pragmatic themes according to existing frameworks (Redecker et al, 2011; Vermunt et al., 2018) and to ensure external validity. Another limitation is that qualitative studies that investigated the effects of analytics-informed LDs on students' perceived performance and learning were not included.

\section{Results}

\subsection{Overview of the Selected Studies}

\subsubsection{Phase One}

To answer RQ1 and RQ2 for the development of the new LALGD model, 25 key studies (18 journal articles, 7 conference proceedings) identified in Phase One of the current review underwent an in-depth analysis (see Supplementary Table S3). Initially, 172 studies were considered after applying the inclusion and exclusion criteria (Figure 1). A large number $(n=71$ or $41 \%$ ) of those were published at conferences. This is not surprising due to the relatively new field of LA and the dissemination of novel research findings via conferences. Limiting the search criteria to journal articles would have significantly reduced the number of eligible studies.

The selected studies were representative of the HE sector globally, being conducted at medium to large public universities across five continents involving mainly undergraduate students (68\% of studies), ranging from small studies with only 24 students (Goggins \& Xing, 2016) to very large studies involving hundreds or thousands of students (Corrigan, Smeaton, Glynn, \& Smyth, 2015; Milliron et al., 2014). Fifteen studies applied convenience (purposive) sampling, and seven assigned students to a control group. Randomization of participating students was rare $(n=3)$.

The majority of studies were conducted within fully online $(n=11)$ and blended $(n=8)$ courses. For this study, blended learning, if not specifically stated, was a scenario whereby students attended lectures on campus (face-to-face instruction) combined with online modes of learning, which is a commonly accepted definition. Twenty-three studies required students to complete assignments to earn grades, marks, final exams, a pass/fail, etc., as part of the course work, except for MOOCs (Adamopoulos, 2013) and a summer bridging course (Giesbers, Rienties, Tempelaar, \& Gijselaers, 2013). There was an apparent gap of representative studies from the arts and humanities - most students were enrolled in traditionally quantitative disciplines: computing and engineering $(n=14)$, business and economics $(n=6)$, and science $(n=2)$. Li, Lam, and Lam (2015) argued that STEM subjects are heavily reliant on technology-enhanced learning, which may well drive some of the LA research in need of computational models appropriated from other disciplines.

\subsubsection{Phase Two}

A refined search identified 145 out of 1276 studies covering the period April 2016 to 2019. After assessing the studies according to the criteria in steps 2 and 3,13 were selected for inclusion. The characteristics were similar to the academic papers described for Phase One, that is, conducted in Europe (4), the United States (2), Asia (2), and Australia (4), with sample sizes ranging from under 100 students (3 studies) to large and very large (9) cohorts; one was of medium size. In alignment with the proposed LALGD model (Figure 3, below), the selected studies were mapped onto collaborative (3), independent (6), and personalized learning (4), as summarized in Supplementary Table S4.

\subsection{The Use of LA in Collaborative, Independent, and Personalized Learning (RQ1)}

\subsubsection{LA Data Sources}

Analysis of the key studies found no single definition of learning outcome, which was mainly derived from assessment

ISSN 1929-7750 (online). The Journal of Learning Analytics works under a Creative Commons License, Attribution - NonCommercial-NoDerivs 3.0 Unported (CC BY-NC-ND 3.0) 
(e.g., Romero-Zaldivar, Pardo, Burgos, \& Delgado Kloos, 2012; Tempelaar, Rienties, \& Giesbers, 2015) and grades or pass rates (e.g., Milliron et al., 2014). Unsurprisingly, the most commonly used data were extracted from digital environments tracking students' total login frequency and time, time spent in discussion forums, and number of submissions. LMS click data are generally considered poor indicators of student engagement (Macfadyen \& Dawson, 2010). To gain a deeper understanding of learning processes for effective LDs, researchers increasingly combined log data with students' learning dispositions (e.g., Tempelaar et al., 2015), indicators of time management (e.g., Giesbers et al., 2013; Jo, Park, Yoon, \& Sung., 2016), and cognition (e.g., Joksimović, Gašević, Kovanović, Riecke, \& Hatala, 2015). To answer RQ1 about what kinds of LA can effectively guide LD to support teaching practice, the 25 studies were characterized according to collaboration, independent learners, and personalization as follows.

\section{Collaboration - Social Learning and Collective Efficacy}

The nine studies summarized under this theme focus on student-to-student and/or student-to-instructor interactions (Table 1). A key finding is that teacher-assigned roles and scaffolds in online collaborative spaces can improve student performance by optimizing cognitive as well as social presence. A good example of how to achieve this is by Gašević, Adesope, Joksimović, and Kovanović (2015), whereby role assignment in asynchronous discussions supported collaborative learning and produced high cognitive presence, indicating a deeper engagement with the subject matter. Moreover, teacher presence via moderation of online discussions supported the development of students' social presence (Joksimović, Gašević, Kovanović, et al., 2015). Most studies also reported on moderating variables outside a teacher's control. For example, Giesbers et al. (2013) found high drop-out rates do not always associate with lack of motivation and grouping factors may affect learning performance (Muuro, Oboko, \& Wagacha, 2016). To sum up, social learning opportunities often produced reliable academic performance indicators with high predictive accuracy (77\%) based on students' participation, social network status (prestige), and message quality (Romero, López, Luna, \& Ventura, 2013; Gunnarsson \& Alterman, 2012).

Table 1. Key Studies on Collaboration - Social Learning and Collective Efficacy

\begin{tabular}{|c|c|c|c|c|}
\hline Method & $\begin{array}{l}\text { Context } \\
\text { (Level; UG = } \\
\text { undergraduate; PG } \\
=\text { post-graduate) } \\
\end{array}$ & Objective of study & LA Data & Authors \\
\hline $\begin{array}{l}\text { Social } \\
\text { networks }\end{array}$ & $\begin{array}{l}\text { Computing - } \\
\text { generic (UG) }\end{array}$ & $\begin{array}{l}\text { To apply social analysis in the use } \\
\text { of learning technology and impact } \\
\text { on study success }\end{array}$ & $\begin{array}{l}\text { Moodle analytics, iGoogle, } \\
\text { Google Groups, FriendFeed, } \\
\text { OpenID interaction data in } \\
\text { Python }\end{array}$ & $\begin{array}{l}\text { Casquero, } \\
\text { Ovelar, Romo, } \\
\text { Benito, \& } \\
\text { Alberdi, } 2016 \\
\end{array}$ \\
\hline $\begin{array}{l}\text { Social } \\
\text { networks }\end{array}$ & $\begin{array}{l}\text { Computer science } \\
\text { (UG) }\end{array}$ & $\begin{array}{l}\text { To predict student performance } \\
\text { and pass/fail rates }\end{array}$ & $\begin{array}{l}\text { Number of messages } \\
\text { read/posted, time spent, } \\
\text { message content, social network } \\
\text { centrality and prestige, final } \\
\text { mark }\end{array}$ & $\begin{array}{l}\text { Romero et al., } \\
2013\end{array}$ \\
\hline $\begin{array}{l}\text { Asynchronous } \\
\text { discussions }\end{array}$ & $\begin{array}{l}\text { Computing - } \\
\text { generic }(\mathrm{PG})\end{array}$ & $\begin{array}{l}\text { To investigate the impact of } \\
\text { participation and social dialogue } \\
\text { on student behaviour and learning }\end{array}$ & $\begin{array}{l}\text { Questionnaire (Likert scales) } \\
\text { aligned with social cognitive } \\
\text { theory, student activity logs }\end{array}$ & $\begin{array}{l}\text { Goggins \& Xing, } \\
2016\end{array}$ \\
\hline $\begin{array}{l}\text { Asynchronous } \\
\text { discussions }\end{array}$ & $\begin{array}{l}\text { Software } \\
\text { engineering }(\mathrm{PG})\end{array}$ & $\begin{array}{l}\text { To implement effective } \\
\text { instructional design to develop } \\
\text { cognitive presence in student-led } \\
\text { discussions }\end{array}$ & $\begin{array}{l}\text { Quantitative content analysis of } \\
\text { posts (triggering event, } \\
\text { exploration, integration, } \\
\text { resolution), total number of } \\
\text { posts }\end{array}$ & $\begin{array}{l}\text { Gašević, } \\
\text { Adesope, et al., } \\
2015\end{array}$ \\
\hline $\begin{array}{l}\text { Asynchronous } \\
\text { discussions }\end{array}$ & $\begin{array}{l}\text { Software } \\
\text { engineering }(\mathrm{PG})\end{array}$ & $\begin{array}{l}\text { To investigate the moderating role } \\
\text { of teaching and social presence in } \\
\text { a community of inquiry on } \\
\text { performance }\end{array}$ & $\begin{array}{l}\text { Content analysis of posts using } \\
\text { social presence indicators as } \\
\text { predictors, final grade }\end{array}$ & $\begin{array}{l}\text { Joksimović, } \\
\text { Gašević, } \\
\text { Kovanović, et } \\
\text { al., } 2015\end{array}$ \\
\hline Co-blogging & $\begin{array}{l}\text { Computer science } \\
(\mathrm{UG}+\mathrm{PG})\end{array}$ & $\begin{array}{l}\text { To improve academic outcome } \\
\text { through enhanced participation } \\
\text { and predictive analytics }\end{array}$ & $\begin{array}{l}\text { Number of post reads created by } \\
\text { other users, grades }\end{array}$ & $\begin{array}{l}\text { Gunnarsson \& } \\
\text { Alterman, } 2012\end{array}$ \\
\hline Group work & $\begin{array}{l}\text { Computer science, } \\
\text { math (UG) }\end{array}$ & $\begin{array}{l}\text { To assess different student group } \\
\text { formation on effective } \\
\text { collaboration }\end{array}$ & $\begin{array}{l}\text { Moodle analytics (number of } \\
\text { posts/replies, forum ratings), } \\
\text { grades, pre- and post-test } \\
\text { questionnaire }\end{array}$ & $\begin{array}{l}\text { Muuro et al., } \\
2016\end{array}$ \\
\hline
\end{tabular}

ISSN 1929-7750 (online). The Journal of Learning Analytics works under a Creative Commons License, Attribution - NonCommercial-NoDerivs 3.0 Unported (CC BY-NC-ND 3.0) 
Table 1. (Continued) Key Studies on Collaboration - Social Learning and Collective Efficacy

\begin{tabular}{lllll}
\hline Method & $\begin{array}{l}\text { Context } \\
\text { (Level; UG }= \\
\text { undergraduate; PG } \\
\text { = post-graduate) }\end{array}$ & Objective of study & LA Data & Authors \\
\hline $\begin{array}{l}\text { Problem-based } \\
\text { learning (PBL) }\end{array}$ & $\begin{array}{l}\text { Computing } \\
\text { engineering (UG) }\end{array}$ & $\begin{array}{l}\text { To assess the effect of formative } \\
\text { assessment methods (self, peer, } \\
\text { external, instructor) on outcome }\end{array}$ & $\begin{array}{l}\text { Likert scale items to measure } \\
\text { assessment outcomes of } \\
\text { students' PBL task products }\end{array}$ & $\begin{array}{l}\text { Domínguez, } \\
\text { Jaime, Sánchez, } \\
\text { Blanco, \& Heras, } \\
\text { 2016 }\end{array}$ \\
\hline $\begin{array}{l}\text { Problem-based } \\
\text { learning - } \\
\text { video }\end{array}$ & Business (UG) & $\begin{array}{l}\text { To inform design guidelines for e- } \\
\text { learning through synchronous } \\
\text { conferencing }\end{array}$ & $\begin{array}{l}\text { Academic Motivation Scale } \\
\text { (AMS) survey (Likert scales), }\end{array}$ & $\begin{array}{l}\text { Giesbers et al., } \\
\text { 2013 } \\
\text { motivation, and performance }\end{array}$ \\
\hline
\end{tabular}

\section{Independent Learners - Self-Regulation and Real-Life Learning}

A common theme in Table 2 is that effective LDs facilitate independent learning by encouraging students to reflect on their progress and take necessary steps to adjust their study behaviour in order to do well. Researchers showed increased awareness of capturing more nuanced LA that reflected students' cognitive and metacognitive skills. These included learner-controllable factors such as time management (e.g., Yu \& Jo, 2014; Jo et al., 2016), self-efficacy (Adamopoulos, 2013), and academic procrastination (You, 2015), which are easily obtainable LA upon which teachers can act. Also, giving students choices of resources can have a positive impact on academic performance (Martínez-Muñoz \& Pulido, 2015). Consequently, successful LDs included those that fostered active participation within social constructivist, assessment-driven, and balanced-variety designs (Rienties et al., 2015). Another important finding was that students' learning trajectories (cognitive skills) during authentic tasks were far more reliable predictors of learning outcome than LA from LMS activities (e.g., Blikstein et al., 2014; Romero-Zaldivar et al., 2012). Interestingly, students spending more time communicating with teachers negatively influenced outcomes (Joksimović, Gašević, Loughin, Kovanović, \& Hatala, 2015).

Table 2. Key Studies on Independent Learners - Self-Regulation and Real-Life Learning

\begin{tabular}{|c|c|c|c|c|}
\hline Method & $\begin{array}{l}\text { Context } \\
\text { (Level) }\end{array}$ & Objectives of study & LA sources & Authors \\
\hline Virtual machine & $\begin{array}{l}\text { Software } \\
\text { engineering } \\
\text { (UG) }\end{array}$ & $\begin{array}{l}\text { To monitor learning processes } \\
\text { (virtual machine) to predict } \\
\text { achievement }\end{array}$ & $\begin{array}{l}\text { Student usage data/programming tasks, } \\
\text { log data of software applications, final } \\
\text { grades }\end{array}$ & $\begin{array}{l}\text { Romero- } \\
\text { Zaldivar et al., } \\
2012\end{array}$ \\
\hline Online coding & $\begin{array}{l}\text { Computing } \\
\text { skills (UG) }\end{array}$ & $\begin{array}{l}\text { To inform course design and } \\
\text { real-time feedback using } \\
\text { learning process }\end{array}$ & $\begin{array}{l}\text { Size, frequency of online code update; } \\
\text { number of lines and characters added, } \\
\text { deleted, modified }\end{array}$ & $\begin{array}{l}\text { Blikstein et } \\
\text { al., } 2014\end{array}$ \\
\hline $\begin{array}{l}\text { Self-regulation: } \\
\text { procrastination }\end{array}$ & $\begin{array}{l}\text { General } \\
\text { education } \\
\text { (UG) }\end{array}$ & $\begin{array}{l}\text { To investigate the effects of } \\
\text { online academic procrastination } \\
\text { on achievement }\end{array}$ & $\begin{array}{l}\text { LMS log data; procrastination } \\
\text { indicators as failure of self-regulated } \\
\text { learning, i.e., delays in weekly } \\
\text { scheduled study, late submission of } \\
\text { assignments }\end{array}$ & 15 \\
\hline $\begin{array}{l}\text { Self-regulation: } \\
\text { time } \\
\text { management }\end{array}$ & $\begin{array}{l}\text { Business } \\
\text { statistics } \\
(\mathrm{UG}+\mathrm{PG})\end{array}$ & $\begin{array}{l}\text { To investigate time } \\
\text { management in relation to } \\
\text { psychological factors of } \\
\text { learning }\end{array}$ & $\begin{array}{l}\text { Moodle log data, Time and Study } \\
\text { Environment Management (TSEM) } \\
\text { survey (Likert scores) }\end{array}$ & 2016 \\
\hline $\begin{array}{l}\text { Self-regulation: } \\
\text { achievement } \\
\text { optimization }\end{array}$ & $\begin{array}{l}\text { Business } \\
\text { studies (UG) }\end{array}$ & $\begin{array}{l}\text { To identify (student-) } \\
\text { controllable components for } \\
\text { improved achievement }\end{array}$ & $\begin{array}{l}\text { LMS data: total login and time; } \\
\text { regularity of learning interval; number } \\
\text { of downloads; peer and instructor } \\
\text { interactions; final grade }\end{array}$ & $\begin{array}{l}\text { Yu \& Jo, } \\
2014\end{array}$ \\
\hline $\begin{array}{l}\text { Distance } \\
\text { education: design } \\
\text { validation }\end{array}$ & $\begin{array}{l}\text { Various } \\
(\mathrm{UG}+\mathrm{PG})\end{array}$ & $\begin{array}{l}\text { To understand the role of design } \\
\text { for learning and performance } \\
\text { across } 87 \text { modules }\end{array}$ & $\begin{array}{l}\text { Static and dynamic LMS data: total } \\
\text { number of visits, average time spent in } \\
\text { LMS }\end{array}$ & $\begin{array}{l}\text { Rienties et al., } \\
2015\end{array}$ \\
\hline $\begin{array}{l}\text { Distance } \\
\text { education: design } \\
\text { validation }\end{array}$ & $\begin{array}{l}\text { Information } \\
\text { systems } \\
\text { (UG }+ \text { PG) }\end{array}$ & $\begin{array}{l}\text { To promote effective } \\
\text { pedagogical design in online } \\
\text { learning through LA versus } \\
\text { self-reports }\end{array}$ & $\begin{array}{l}\text { Moodle data: total count; total time } \\
\text { spent; interactions with other students, } \\
\text { content, teachers, systems }\end{array}$ & $\begin{array}{l}\text { Joksimović, } \\
\text { Gašević, } \\
\text { Loughin, et } \\
\text { al., } 2015\end{array}$ \\
\hline
\end{tabular}


Table 2. (Continued) Key Studies on Independent Learners - Self-Regulation and Real-Life Learning

\begin{tabular}{lllll}
\hline Method & $\begin{array}{l}\text { Context } \\
\text { (Level) }\end{array}$ & Objectives of study & LA sources & Authors \\
\hline $\begin{array}{l}\text { MOOC: } \\
\text { design validation }\end{array}$ & $\begin{array}{l}\text { Range of } \\
\text { subjects } \\
\text { (N/A) }\end{array}$ & $\begin{array}{l}\text { To identify determinants that } \\
\text { affect student retention in online } \\
\text { courses }\end{array}$ & $\begin{array}{l}\text { Demographics; sentiments (discussion } \\
\text { posts, course materials); workload } \\
\text { estimate; course progress; difficulty; } \\
\text { course completion, drop-out }\end{array}$ & $\begin{array}{l}\text { Adamopoulos, } \\
2013\end{array}$ \\
\hline $\begin{array}{l}\text { Flipped } \\
\text { classroom: } \\
\text { design validation }\end{array}$ & $\begin{array}{l}\text { Engineering } \\
\text { (UG) }\end{array}$ & $\begin{array}{l}\text { To reduce drop-out and increase } \\
\text { study performance through } \\
\text { course redesign }\end{array}$ & $\begin{array}{l}\text { SPOC usage data (access, time spent), } \\
\text { test results, marks, student satisfaction } \\
\text { (evaluations) }\end{array}$ & $\begin{array}{l}\text { Martínez- } \\
\text { Muñoz \& } \\
\text { Pulido, 2015 }\end{array}$ \\
\hline
\end{tabular}

Personalization - Tailored Learning and Predictive Analytics

While disciplinary differences, technology use, and LD have consequences for the generalizability of predictive models (Gašević et al., 2016), the majority of studies shown in Table 3 advocated the use of predictive analytics to enable more targeted learning interventions. Specifically, authors utilized personalized email messages (Corrigan et al., 2015; Dodge, Whitmer, \& Frazee, 2015; Milliron et al., 2014) or visual graphics (Ott, Robins, Haden, \& Shephard, 2015; Tabuenca, Kalz, Drachsler, \& Specht, 2015) based on individuals' engagement and/or performance data. The main concerns for this type of learning intervention were about student retention (Gašević et al., 2016; Milliron et al., 2014) and timely feedback to those most at risk of failing (e.g., Corrigan et al., 2015). The impact on final grades varied greatly among studies, ranging from no overall effect (Ott et al., 2015) to only affecting subgroups of students (Dodge et al., 2015). Moreover, analytics-based nudges that provided detailed information about progress and support provisions were more effective than generic tips (Tabuenca et al., 2015). The type of outreach (email or phone call) and students' stage of study also played a role. Importantly, for personalized interventions to improve outcomes, LA related to students' cognitive processes (e.g., formative assessment data combined with engagement data) were far more effective than LMS activity alone (Tempelaar et al., 2015).

Table 3. Key Studies on Personalization - Tailored Learning and Predictive Analytics

\begin{tabular}{|c|c|c|c|c|}
\hline Method & Context (Level) & Objective & Data sources & Authors \\
\hline $\begin{array}{l}\text { Predictive } \\
\text { analytics: } \\
\text { engagement }\end{array}$ & Various (UG) & $\begin{array}{l}\text { To improve engagement with the } \\
\text { LMS environment }\end{array}$ & Moodle trace data, grades & $\begin{array}{l}\text { Corrigan et } \\
\text { al., } 2015\end{array}$ \\
\hline $\begin{array}{l}\text { Predictive } \\
\text { analytics: } \\
\text { engagement }\end{array}$ & $\begin{array}{l}\text { Psychology, } \\
\text { statistics (UG) }\end{array}$ & $\begin{array}{l}\text { To nudge students at risk using } \\
\text { personalized emails }\end{array}$ & $\begin{array}{l}\text { LMS logins, exam and quiz grades, } \\
\text { clicker points as proxy for lecture } \\
\text { attendance }\end{array}$ & $\begin{array}{l}\text { Dodge et } \\
\text { al., } 2015\end{array}$ \\
\hline $\begin{array}{l}\text { Predictive } \\
\text { analytics: } \\
\text { engagement }\end{array}$ & $\begin{array}{l}\text { Computer } \\
\text { science (UG) }\end{array}$ & $\begin{array}{l}\text { To support self-regulated learning } \\
\text { using infographics as feedback }\end{array}$ & $\begin{array}{l}\text { Pre-course grades, submission } \\
\text { timeliness at week } 8 \text {, completion of } \\
\text { tasks/labs weeks } 5 \text { and } 11, \text { mid- } \\
\text { semester score, final exam score }\end{array}$ & $\begin{array}{l}\text { Ott et al., } \\
2015\end{array}$ \\
\hline $\begin{array}{l}\text { Predictive } \\
\text { analytics: time } \\
\text { management }\end{array}$ & $\begin{array}{l}\text { Psychology, } \\
\text { geography (UG) }\end{array}$ & $\begin{array}{l}\text { To support self-regulated learning } \\
\text { in online environment }\end{array}$ & $\begin{array}{l}\text { Learn Tracker app recordings, web } \\
\text { log data (subject, time stamp, } \\
\text { duration of activity), Likert scales }\end{array}$ & $\begin{array}{l}\text { Tabuenca et } \\
\text { al., } 2015\end{array}$ \\
\hline $\begin{array}{l}\text { Predictive } \\
\text { analytics: } \\
\text { cognition }\end{array}$ & $\begin{array}{l}\text { Business and } \\
\text { economics (UG) }\end{array}$ & $\begin{array}{l}\text { To determine effective and timely } \\
\text { performance indicators }\end{array}$ & $\begin{array}{l}\text { Demographics, diagnostic tests, } \\
\text { learning dispositions (Likert scale), } \\
\text { BlackBoard logs, external e-tutorial } \\
\text { scores, final exam mark }\end{array}$ & $\begin{array}{l}\text { Tempelaar } \\
\text { et al., } 2015\end{array}$ \\
\hline $\begin{array}{l}\text { Predictive } \\
\text { analytics: } \\
\text { persistence }\end{array}$ & Various (UG) & $\begin{array}{l}\text { To determine effective indicators of } \\
\text { student success, study persistence, } \\
\text { and re-enrollment }\end{array}$ & $\begin{array}{l}\text { Student information, LMS activity, } \\
\text { GPA, credits earned as proxy for } \\
\text { engagement (Civitas Inspire score) }\end{array}$ & $\begin{array}{l}\text { Milliron et } \\
\text { al., } 2014\end{array}$ \\
\hline $\begin{array}{l}\text { Predictive } \\
\text { analytics: } \\
\text { success }\end{array}$ & $\begin{array}{l}\text { First-year } \\
\text { experience (UG) }\end{array}$ & $\begin{array}{l}\text { To investigate the impact of } \\
\text { instructional design on success and } \\
\text { attrition across blended courses }\end{array}$ & $\begin{array}{l}\text { Moodle trace data, student data } \\
\text { (grades, demographics) }\end{array}$ & $\begin{array}{l}\text { Gašević et } \\
\text { al., } 2016\end{array}$ \\
\hline
\end{tabular}

\subsection{Effectiveness of LA for an Integrated Data-to-Design-to-Outcomes Model (RQ2)}

\subsubsection{Overview of Reported Effects}

The analysis of effect sizes reported in the 25 key papers from Phase One of this study revealed 77 main effects (see Supplementary Table S3 for coding, recalculated Cohen's $d$, and Pearson $r$ ). These are summarized by learning gain, 
instructional method, sample size, and level of effect in Figure 2. A key finding is that activities that fostered social collaboration consistently yielded medium to large effects on performance and course outcome, through the development of students' cognitive and metacognitive skills (Table 4). Learning interventions appealing to the affective domain of learning, such as analytics-informed infographics and email nudges, had no or little overall effect on course outcome and performance (Table 4). The influences of instructional methods on learning gains through the lens of LA can be summarized as follows.

\section{Cognitive Gains}

As mentioned earlier, LMS engagement remains a weak predictor of students' final grades, while learning tasks that foster deep learning and are meaningful within students' contexts are strongly associated with improved achievement (3\% versus $21.8 \%$ variance explained, respectively; Romero-Zaldivar et al., 2012). Some of the larger effects $(d=1.6$ and $d=1.05)$ stemmed from students' independent learning and meaning making, which can be gleaned from actual learning trajectories in virtual spaces (Blikstein et al., 2014; Romero-Zaldivar et al., 2012). Self-steered formative assessment, such as students' time spent in e-tutorials and mastery of specific tasks, also had a large impact on learning performance $(d=1.13$; Tempelaar et al., 2015).

\section{Metacognitive Gains}

This category comprised the largest proportion of medium to large effect sizes (77\%). The greatest overall impact of LD activities was related to online presence (Figure 2; also Table 4), pointing to the importance of embedded supports that enable students to monitor and adjust their learning behaviour through time management, self-reflection, and interactions with peers and teachers (e.g., $d=0.88$; Domínguez et al., 2016). Academic procrastination behaviour as an indicator of failed selfregulation, such as online absence and late submissions, had large negative effects on students' final scores $(d=-1.41$ and $d$ $=1.16$, respectively; see You (2015) in Supplementary Table S3).

\section{Socio-Communicative Gains}

Students' increased social and cognitive presence in online learning communities to a large extent associates with improved learning performance and course outcome. As can be seen from Figure 2, cognitive indicators of students' level of understanding captured via message quality of online discussion posts had a large effect on performance (Goggins \& Xing, 2016) and pass rates (Romero et al, 2013). Learning outcomes were highly influenced by peers' comments, students' social ability, and collective efficacy, resulting in medium $(d=0.7)$ to large $(d=1.1)$ effects on learning performance (e.g., Casquero et al., 2016; Goggins \& Xing, 2016). Another important aspect is a student's social network status, such as centrality and prestige, which can have large effects on supporting students' online presence ( $d=1.29$; Romero et al., 2013), impacting performance downstream.

\section{Affective Gains}

There is no doubt that learning emotions impact student outcomes. However, the overall impact of affect found in this meta-analysis was negligible. Adamopoulos (2013) found that negative sentiments in discussion forums impacted completion with a small effect $(d=0.1)$, while posts expressing appreciation or complimenting others were negative predictors of outcome $(d=-0.08$; Joksimović, Gašević, Kovanović, et al., 2015). Personalized learning interventions appear to be most effective for those most in need, for example, students from lower socioeconomic backgrounds, rather than lifting overall achievement; however, the effects were negligible (Corrigan et al., 2015) to small (Dodge et al., 2015). Milliron et al. (2014) found that email messages combined with supports from academic advisors increased course completion threefold, whereas nudges alone were only effective for those students identified as at risk, with a very small effect size $(d=0.013)$. Researchers remarked that personalized interventions using affective and metacognitive cues (encouragement, connectedness, and revealing individual progress) in an attempt to modify students' learning behaviour were often not enough to trigger substantial action to improve overall outcome.

Table 4. Summary Statistic of Effect Sizes on Learning Outcomes by Learning Gain

\begin{tabular}{|c|c|c|c|c|}
\hline $\begin{array}{l}\text { Mean/Range } \\
\text { (Cohen's } d \text { ) }\end{array}$ & $\begin{array}{c}\text { Cognitive } \\
n=19\end{array}$ & $\begin{array}{c}\text { Metacognitive } \\
n=21\end{array}$ & $\begin{array}{c}\text { Socio-Communicative } \\
n=22\end{array}$ & $\begin{array}{c}\text { Affective } \\
n=16\end{array}$ \\
\hline Course outcome & $-0.19(-0.69-0.24)$ & $0.13(0.10-0.14)$ & $0.56(0.42-0.70)$ & $0.09(0.00-0.35)$ \\
\hline Learning performance & $0.56(0.01-1.61)$ & $-0.13(-1.41-0.61)$ & $1.11(0.03-2.69)$ & $0.16(-0.08-1.07)$ \\
\hline Online presence & NR & $0.87(0.30-2.47)$ & $1.08(0.03-2.22)$ & NR \\
\hline
\end{tabular}

Note: Means in bold are medium $(\geq 0.35$ or $<0.65)$ or large $(\geq 0.66)$ effects based on Schneider and Preckel's (2017) classification. NR, not reported in the primary studies. A total of 77 main effects were extracted from 25 key papers. 

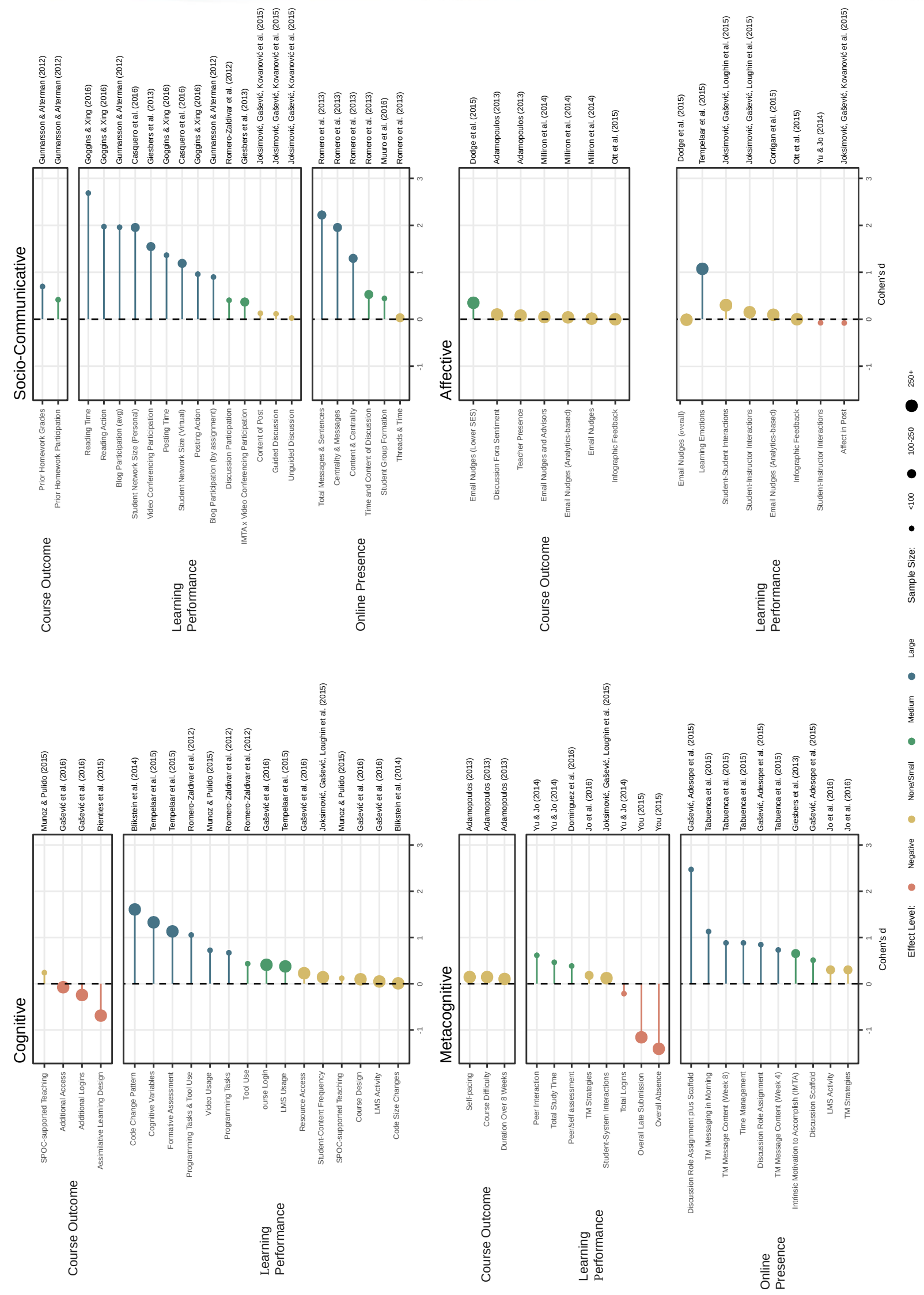

Figure 2. Forest plots of effects sizes $(n=77)$ extracted from studies included in Phase One of this review. Cut-off values for Cohen's $d$ are based on Schneider and Preckel (2017); sample sizes are according to Cheung and Slavin (2016) 
Finally, to guide design decisions based on LA that were shown to be effective indicators of student learning gains, the author proposes the consolidated LALGD model, as shown in Figure 3. This model incorporates existing concepts of future education strategies in response to the worldwide challenges of meeting employment markets, ensuring equitable access to education, and increasing online and blended learning as proposed by Redecker et al. (2011). Redecker et al.'s three main concepts (ways of learning) were mapped onto effective LA data derived from the meta-analysis of selected studies, establishing the link between pedagogic intentions and meaningful data capture on one hand, and desired outcomes (learning gains) informed by Vermunt et al. (2018) on the other. While the complex relationships between behavioural and cognitive learning processes and instructional methods cannot be fully integrated into one model, the aim of the proposed LALGD model is to emphasize LA for learning gain, that is, focusing on student outcomes. It is intended to enable dialogue between teachers and learning designers to situate expectations around outcomes when designing for learning with data in mind. The following section explores the utility of the LALGD model based on the findings from Phase Two of the current review and how it could be applied to broader educational goals.

\section{Learning Gain Design $\quad$ Ways of Learning Learning Analytics}

\section{Socio-communicative:}

- Fostering relatedness

- Peer support

- Role assignment

- Setting expectations

Cognitive/metacognitive:

- Authentic learning

- Checking understanding

- Scaffolding timeliness

- Student reflections

Metacognitive/affective:

- Teacher presence

- Student belonging

- Revealing progress

- Analytics-based feedback

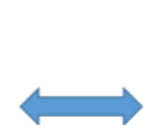

Collaboration

Social learning Collective efficacy

Independent learners Self-regulation Real-life learning

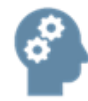

- Social network indicators

- Posts timing, reading, quality

- Group formation factors

- Group sentiments

- Learning patterns, trajectories

- Formative assessment

- Time management indicators

- Motivation indicators

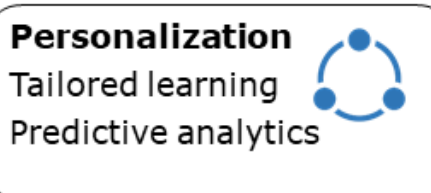

- Engagement indicators

- Demographics

- Feedback triggers

- Time on task

- Learning dispositions

Figure 3. The LALGD model

Note: The bi-directional links between ways of learning (adapted from Redecker et al., 2011) are based on the meta-analysis of effect sizes to support learning design approaches toward socio-communicative, cognitive, metacognitive, and affective learning gains (adapted from Vermunt et al., 2018) on the left and meaningful LA data capture on the right. LA indicators need to be based on pedagogic intent, and overlaps may occur between categories; for example, learning patterns might be used as a feedback trigger to personalize student learning.

\subsection{Evaluating the Model in Light of the Evidence from Phase Two (RQ3)}

Through the systematic analysis of the 13 selected studies from Phase Two of this research, it became increasingly obvious that the newly developed LALGD model shown in Figure 3 could be further developed and applied to broader issues in today's HE. To fully understand its value for practice, the empirical evidence is viewed through the lens of enablers and barriers to support LA-informed student agency, outcomes-focused LA for retention, and curriculum development as follows.

\subsubsection{The LALGD Model as Data-Informed Student Agency}

One way to relate the LALGD model to practice is by way of supporting student agency through LA-based personalized and tailored feedback to students (e.g., Dawson, Jovanović, Gašević, \& Pardo, 2017; Pardo, Jovanović, Dawson, Gašević, \& Mirriahi, 2019). Examples of how to support student agency include timed adaptive release of activities to support time on task (Martin \& Whitmer, 2016); dashboards that reveal students' learning behaviour (Rubio, Thomas, \& Li, 2018); and methods that model positive self-regulation, countering negative learning emotions (Pardo, Han, \& Ellis, 2017). Essentially, this type of intervention puts the data back into students' hands and enables reflection on their own progress. While the targeted interventions were perceived favourably by students, and at times produced large effects (e.g., Zhang et al., 2019), the overall impact on academic outcome varied greatly (Cohen's $d=0.14$ to 1.63 , mean $=0.69, \mathrm{SD}=0.49, n=12$ effects; see Supplementary Table S4). Learners valued tailored feedback over undifferentiated, non-individualized messages (Zhang et al., 
2019; Akhtar, Warburton, \& Xu, 2017) and comparisons between their previous and current performance (Schumacher \& Ifenthaler, 2018). In practice, LDs need to predetermine triggers or key indicators of learning/progress to enable LA capture that can inform appropriate actions. Automated systems such as OnTask (Pardo et al., 2019), whereby rules of engagement and/or disengagement can be set up in advance, can be helpful. Barriers to adoption by teachers in the classroom may include a need for training in collection and use of data, capability of systems to enable integration of LA, and increased staff costs to allow for the scaling of personalization in large courses (author's own observations).

\subsubsection{The LALGD Model as Outcomes-Focused LA}

As previously stated, LD activities that foster cognition and metacognition had a large impact on learning gains and students' online presence (Supplementary Table S4). Independent learner activities are crucial design elements for improving outcomes. However, there was large variation in the reported effects sizes on gains using independent learning $(d=0.09$ to 3.2 , mean $=$ $0.97, \mathrm{SD}=0.80, n=18)$ and socio-collaborative approaches $(d=0.24$ to 2.34 , mean $=0.67, \mathrm{SD}=0.60, n=10)$, complicating LD decisions about improving student retention and perseverance. For example, personalized call campaigns targeting at-risk students had little impact $(d=0.142)$ on re-enrollment despite predictive models promising larger effects $(31 \%$; see Dawson et al., 2017). This was likely due to other student-specific features, for example, demographics, academic load, and whether a student responded to an intervention attempt.

The findings from Phase Two revealed the importance of capturing rich data contexts, such as motivational dispositions to enable interventions that are engaging and empowering for students (Tempelaar et al., 2018). This confirmed the already mentioned shift to a more holistic approach to improving student outcomes and experience (e.g., Pardo et al., 2019; Schumacher \& Ifenthaler, 2018), as well as their self-efficacy (e.g., Jovanović, Gašević, Pardo, Dawson, \& Whitelock-Wainwright, 2019), self-regulation (e.g., Kim, Yoon, Jo, \& Branch, 2018; Pardo et al., 2017), and emotions (e.g., Tempelaar et al., 2018). Utilizing rich data contexts can help with students' self-reflection and evaluation of their learning for improved outcomes. A caveat is that these often rely on self-reports, which either are difficult to obtain or may suffer from selection bias (e.g., Jovanović et al., 2019). The LALGD model can help us to situate our expectations of student outcomes and pair these with instructional methods (ways of learning) linked to relevant LA. However, effective interventions showing high impact in one context may differ in others, which needs to be considered when applying the model to practice.

\subsubsection{The LALGD Model as Data-Informed Curriculum Design}

The LALGD model is aimed at encouraging dialogue among key stakeholders involved in the planning and development of curriculum, to help design learning for student success. Much can be gleaned from LA on the effectiveness of instructional methods on specific outcomes. Nguyen, Rienties, Toetenel, Ferguson, and Whitelock (2017) found that the type of LD activities strongly influenced academic retention. Their study of over 70 modules involving 72 thousand students concluded that assimilative activities and fewer student-centred approaches received significantly higher evaluation scores but had no correlation to retention. Socio-collaborative learning was seen as an enabler of effective online learning, shifting the focus away from cognitive learning. In addition, students' goal-setting ability was an important regulator of metacognitive skills and highly correlated with self-regulation, time management, and achievement (Kim et al., 2018). While the LALGD model can be helpful in mapping LA to instructional approaches and outcomes, levels and assessment criteria are not included, requiring contextualization and alignment to other taxonomies of learning (e.g., Biggs, 1996). In addition, design considerations of physical and online environments greatly influence the way students learn; this aspect is not represented in the model. For example, Kim et al. (2018) suggested that students benefit from virtual spaces that encourage help-seeking behaviour and metacognitive feedback in asynchronous online learning spaces, while certain seating configurations in lab-based teaching can improve student performance (Akhtar et al., 2017).

\section{Discussion}

This study has exemplified the complex relationships that exist between LA, LD, and learning outcomes/gains. LA associated with students' academic and behavioural engagement (e.g., Papamitsiou \& Economides, 2014; Joksimović et al., 2018, Tempelaar et al., 2018) showed considerable overlap across cognitive, metacognitive, and affective learning domains. In the absence of an overarching definition of learning outcomes among the selected studies, generalization about the most effective LD approach is not possible and corroborates others' findings (e.g., Gašević et al., 2016; Mangaroska \& Giannakos, 2019; Joksimović et al., 2018). Evans et al. (2018) poignantly state that "learning gain is a messy business" (p. 37) and advise on taking a pragmatic approach to what is feasible and sustainable in specific contexts, satisfying the aim of the newly developed LALGD model (Figure 3). Affective and emotional learning indicators were rarely measured, possibly due to limited access to such data. Progress in multimodal LA research to understand digital engagement may be possible in the future via machinereadable behavioural and physiological cues (D’Mello, Dieterle, \& Duckworth, 2017). 
The present systematic analysis also revealed that LA research increasingly incorporated qualitative and contextual data, beyond the opportunistic capture of student LMS logs, to gain a more holistic insight into learning. While several instruments and tools exist for the measurement and collection of affective-emotional and metacognitive variables (e.g., Rienties \& Alden, 2014), it is unlikely that these have been adopted more broadly. Therefore, it is not surprising that common measures of cognitive (e.g., scores, grades, formative feedback) and behavioural (e.g., LMS traces on submission, participation) engagement formed the bulk of LA data capture in the selected studies.

Another finding indicates that LA were primarily used to (1) check on LD; (2) gain actionable insight into students' interactions with content, resources, and supports; and (3) predict outcomes. Not only does LA provide information about LD characteristics and what the student does, it can also prompt redesign based on what the evidence says. While this notion aligns with existing LA-LD models (e.g., Lockyer et al., 2013; Bakharia et al., 2016), the newly conceptualized LALGD model (Figure 3) is distinctly different. Its pragmatic approach gives practitioners a high-level overview of pedagogic intent (ways of learning), linked to LA capture in one direction, and designing for learning gain in the other based on empirical evidence.

In the context of predictive analytics for personalized, tailored interventions, the current study identified a gap in the LA research. Email nudges or infographics directed at students about their engagement had variable to little impact on academic performance (Figure 2). It is intriguing that such personalized feedback did not seem to be enough to move students in the direction of improving overall, as mentioned by several authors (e.g., Gunnarson \& Alterman, 2012). Also, there was no clear definition of which type of nudge or prompt would be best suited to which intended outcome. In particular, knowledge about how students appraise such information to evoke sustained change in learning behaviours would benefit practice of targeted rather than generic interventions. This is something that would be worthwhile exploring in future research.

\subsection{Pitfalls of Basing Learning Outcomes on Effect Size}

Effective teaching relies on both design and what the teacher does. Most studies on the impact of instructional methods on learning outcomes report at least one moderator effect (Schneider \& Preckel, 2017; Hattie, 2015), warranting caution against the generalizability of effects (e.g., Ferguson \& Clow, 2017; Gašević et al., 2016). Cheung and Slavin (2016) found that research design can impact effect sizes, likely through greater variability or increased contextual factors, making it difficult to reliably replicate patterns of student engagement in contextually different courses (e.g., Ferguson \& Clow, 2015). The predictive power of identifying students at risk can also be unreliable. Jayaprakash, Moody, Lauría, Regan, and Baron (2014) demonstrated a predictive model that was successful in one setting but variable in four others, confirming the claim by Milliron et al. (2014) that "there is no global predictive model that works across institutions with any level of accuracy..." (p. 78). Some instructional variables identified across a program or an institution may not be relevant at course level at all (Gašević et al., 2016). In summary, interpreting effect sizes for the evaluation of educational programs and individual learning interventions requires caution. The findings of the present study clearly point to differences in the magnitude of learning improvements under the influence of various LDs. Hattie (2015) suggests focusing on the higher-impact learning interventions compared to others, because that is where the main message becomes obvious. While this is a good starting point, the magnitude of learning improvements might well be a combination of several smaller effects, for example, integrating learning dispositions (which had a small effect on outcomes) with formative assessment (Tempelaar et al., 2018).

\subsection{Recommendations for Effective LA-Informed Learning Gain Design}

\subsubsection{Collaboration - Social Learning and Collective Efficacy}

Instructional methods prompting peer-to-peer and peer-to-teacher interaction through discussions, collaborative problem solving, and peer assessment had the largest effect on learning gains, confirming previous research (e.g., Schneider \& Preckel, 2017; Hattie, 2015). Importantly, the role of the teacher embodied in social interaction is critical for the development of students' self-regulation, which is "not asocial in nature and origin [and] can be learned from instruction and modelling by teachers and peers" (Zimmerman, 2002, p. 69). This was noted in lab-based seating arrangements, where students sitting in groups and closer to the teacher generally did better (Akhtar et al., 2017). Social presence appears to have a large positive impact on learning performance, for example, through social networks (Goggins \& Xing, 2016) and guided asynchronous discussion forums (Joksimović, Gašević, Kovanović, et al., 2015). Moreover, the time learners spend on communication activities was found to be a primary predictor for academic retention across various LDs (Rienties \& Toetenel, 2016).

\subsubsection{Independent Learners - Self-Regulation and Real-Life Learning}

Embedding real-life, authentic learning tasks, and taking deliberate steps toward developing students' time management, goal setting, and self-efficacy (You, 2015; Kim et al., 2018), can effectively promote cognitive and metacognitive skills. In contrast, LMS click data were generally poor indicators of learning outcomes, with negligible or even negative effects (e.g., Gašević et al., 2016) compared to formative assessment tasks (Tempelaar et al., 2015, 2018). Fostering students' critical thinking and reasoning skills relies on teacher expertise in close proximity to students. For example, project-based tasks such as coding 
simulations can effectively develop cognitive as well as practical skills better than regular lectures (Blikstein et al., 2014; Romero-Zaldivar et al., 2012). In addition, revealing learning trajectories to students can provide real-time feedback for checking their own understanding. Emotions play a critical role in motivation, self-regulation, and achievement (Rienties \& Alden, 2014). Yet, affective learning methods were underrepresented in this review, possibly due to being notoriously difficult to embed, or measure (e.g., Adamopoulos, 2013; Joksimović, Gašević, Loughin, et al., 2015; Tempelaar et al., 2018; Pardo et al., 2017).

\subsubsection{Personalization - Tailored Learning and Predictive Analytics}

Today's increasing class sizes and student diversity make it harder for teachers to provide meaningful feedback at scale. LA has the potential of scaling student feedback based on indicators of student engagement (e.g., Corrigan et al., 2015; Ott et al., 2015; Pardo et al., 2019), time management (Tabuenca et al., 2015), persistence (e.g., Milliron et al., 2014; Dawson et al., 2017), and self-efficacy (e.g., Zhang et al., 2019) in combination with assessment marks. The findings of this review suggest that learning personalization does not have a large impact on overall course completion or academic performance. Maybe the emphasis needs to shift to a more holistic perspective of learning gains across behavioural and academic dimensions, including student well-being and emotional support. Despite recent advances in personalizing learning using embedded LA tools (e.g., Pardo et al., 2019; Blumenstein, Liu, Richards, Leichtweis, \& Stephens, 2018), we need to gain a better understanding of what nudges mean to the learner. Students, especially first years, generally appreciated nudges (Pardo et al., 2017; Pardo et al., 2019), surprised that someone cared about their individual progress and well-being. Nudging also encouraged teachers' reflection on their practice, increasing approachability and awareness of students' needs (McConnell, 2019). Meanwhile, there is no clear definition of how nudges align with learning. A nudge may trigger affective learning based on Vermunt's (1996) definition, "...motivating oneself, attributing learning results to causal factors, attaching subjective appraisals to learning tasks and getting blocking emotions under control" (p. 26).

\section{Conclusion}

LA is positioned at the intersection of theory, LD, and data science (Gašević, Kovanović, \& Joksimović, 2017). Consequently, data about learning is intimately connected with the context in which it occurs and strongly influenced by what the teacher does. This notion is supported in most contemporary educational models, including situated learning (Lave \& Wenger, 1991), constructive alignment (Biggs, 1996), and constructionist learning environments (Laurillard et al., 2013). In the context of realizing strategic educational goals, LA promises to play an important role in practice and policy. There is already much evidence for this trend worldwide through nationally funded projects (e.g., Blumenstein et al., 2018; West, Huijser, \& Heath, 2018). Typically, LA in practice is approached either top-down or bottom-up (Colvin et al., 2015). A top-down approach often implements black-box early detection systems (EDSs) specifically to address student retention and progression across the institution. A bottom-up approach focuses on teacher-led inquiry to optimize teaching and learning at course or program level. In the present review, only one study (Milliron et al., 2014) utilized a proprietary predictive analytics system (Civitas's Illume). Essentially, all others were teacher-led (bottom-up), indicating the crucial role of the practitioner in the evaluation of LD and pedagogy through data-informed decisions.

With respect to predictive analytics models, disciplinary differences, technology use, and design have consequences for generalizability and need to be carefully evaluated against the usefulness of the models in teaching practice (Gašević et al., 2016; Gašević et al., 2017; Sønderlund et al., 2018). More research is needed to be able to navigate the complexity of learning processes and translate the knowledge into local recommendations and/or institutional policy. Process models that make the connections between LD and LA more explicit (e.g., Bakharia et al., 2016; Rienties et al., 2016) are therefore much needed and, importantly, require evaluation for utility with practitioners.

Overall, the findings presented in this review support Evans et al.'s (2018) premise that research-informed learning gain approaches, underpinned by pedagogy and robust methodological perspectives, have the potential to offer actionable insight into the learning processes of all students. The ethical and holistic use of LA as an integral part of LD and delivery (ways of learning) may be a step forward in evoking positive changes to HE by attending to students' and practitioners' agency. The current research contributes to the ongoing development of LA-LD frameworks by providing a practical solution and raising awareness of the effect of data-informed learning and teaching on student success.

\section{Declaration of Conflicting Interest}

The author declared no potential conflicts of interest with respect to the research, authorship, and/or publication of this article.

\section{Funding}

The author declared no financial support for the research, authorship, and/or publication of this article. 


\section{Acknowledgements}

I would like to thank my colleagues, Dr. Jenny McDonald and Dr. Steve Leichtweis (both University of Auckland), for their assistance in synthesizing the data in the early stages of the review process, and especially Jenny for her ongoing constructive feedback that contributed to shaping this paper. Further, I would like to acknowledge Jessica McLay for recalculating the effect sizes and Daniel Barnett for preparing the Forest Plot (both University of Auckland Statistical Consulting Centre), and also the anonymous reviewers for their valuable comments, which greatly improved the final version of this article.

\section{References}

Adamopoulos, P. (2013). What makes a great MOOC? An interdisciplinary analysis of student retention in online courses. In Proceedings of the International Conference on Information Systems (ICIS 2013): Reshaping Society Through Information Systems Design, 15-18 December 2013, Milan, Italy (Vol. 5, pp. 4720-4740). Retrieved from https://aisel.aisnet.org/icis2013/proceedings/BreakthroughIdeas/13/

Akhtar, S., Warburton, S., \& Xu, W. (2017). The use of an online learning and teaching system for monitoring computer aided design student participation and predicting student success. International Journal of Technology and Design Education, 27(2), 251-270. https://dx.doi.org/10.1007/s10798-015-9346-8

Alhadad, S. S., Thompson, K., Knight, S., Lewis, M., \& Lodge, J. M. (2018). Analytics-enabled teaching as design: Reconceptualisation and call for research. In Proceedings of the 8th International Conference on Learning Analytics and Knowledge (LAK '18), 5-9 March 2018, Sydney, Australia (pp. 427-435). New York, NY: ACM. https://dx.doi.org/10.1145/3170358.3170390

Baker, C. (2010). The impact of instructor immediacy and presence for online student affective learning, cognition, and motivation. Journal of Educators Online, 7(1). https://dx.doi.org/10.9743/JEO.2010.1.2

Bakharia, A., Corrin, L., de Barba, P., Kennedy, G., Gašević, D., Mulder, R., ..., Lockyer, L. (2016). A conceptual framework linking learning design with learning analytics. In Proceedings of the 6th International Conference on Learning Analytics and Knowledge (LAK '16), 25-29 April 2016, Edinburgh, UK (pp. 329-338). New York, NY: ACM. https://dx.doi.org/10.1145/2883851.2883944

Biggs, J. (1996). Enhancing teaching through constructive alignment. Higher Education, 32(3), 347-364. https://dx.doi.org/10.1007/BF00138871

Blikstein, P., Worsley, M., Piech, C., Sahami, M., Cooper, S., \& Koller, D. (2014). Programming pluralism: Using learning analytics to detect patterns in the learning of computer programming. Journal of the Learning Sciences, 23(4), 561599. https://dx.doi.org/10.1080/10508406.2014.954750

Blumenstein, M., Liu, D. Y. T., Richards, D., Leichtweis, S., \& Stephens, J. M. (2018). Data-informed nudges for student engagement and success. In J. Lodge, J. C. Horvath, \& L. Corrin (Eds.), Learning analytics in the classroom: Translating learning analytics research for teachers (pp. 185-207). London, UK: Routledge. https://dx.doi.org/10.4324/9781351113038-12

Calvert, C. E. (2014). Developing a model and applications for probabilities of student success: A case study of predictive analytics. Open Learning: The Journal of Open and Distance Learning, 29(2), 160-173. https://dx.doi.org/10.1080/02680513.2014.931805

Casquero, O., Ovelar, R., Romo, J., Benito, M., \& Alberdi, M. (2016). Students' personal networks in virtual and personal learning environments: A case study in higher education using learning analytics approach. Interactive Learning Environments, 24(1), 49-67. https://dx.doi.org/10.1080/10494820.2013.817441

Cheung, A. C., \& Slavin, R. E. (2016). How methodological features affect effect sizes in education. Educational Researcher, 45(5), 283-292. https://dx.doi.org/10.3102\%2F0013189X16656615

Cohen, J. (2013). Statistical power analysis for the behavioral sciences. New York, NY: Routledge. https://dx.doi.org/10.4324/9780203771587

Colvin, C., Rogers, T., Wade, A., Dawson, S., Gašević, D., Buckingham Shum, S., \& Fisher, J. (2015). Student retention and learning analytics: A snapshot of Australian practices and a framework for advancement. Sydney, NSW: Australian Office for Learning and Teaching. Retrieved from https://hdl.handle.net/10453/117173

Conole, G., Gašević, D., Long, P., \& Siemens, G. (2011). Message from the LAK 2011 General and Program Chairs. In G. Conole, \& D. Gašević (Eds.), Proceedings of the 1st International Conference on Learning Analytics and Knowledge (LAK '11), 27 February-1 March 2011, Banff, AB, Canada. New York, NY: ACM. Retrieved from https://dl.acm.org/doi/proceedings/10.1145/2330601

Cooper, A. (2012). What is analytics? Definition and essential characteristics. CETIS Analytics Series, 1(5), 1-10. Retrieved from $\underline{\mathrm{http}} / / /$ publications.cetis.ac.uk/2012/521 
Corrigan, O., Smeaton, A. F., Glynn, M., \& Smyth, S. (2015). Using educational analytics to improve test performance. In G. Conole, T. Klobučar, C. Rensing, J. Konert, \& E. Lavoué (Eds.), Design for teaching and learning in a networked world. Lecture Notes in Computer Science (Vol 9307, pp. 42-55). Cham, Switzerland: Springer.

https://dx.doi.org/10.1007/978-3-319-24258-3_4

Dawson, S., Gašević, D., Siemens, G., \& Joksimović, S. (2014). Current state and future trends: A citation network analysis of the learning analytics field. In Proceedings of the 4th International Conference on Learning Analytics and Knowledge (LAK ’14), 24-28 March 2014, Indianapolis, IN (pp. 231-240). New York, NY: ACM. https://dx.doi.org/10.1145/2567574.2567585

Dawson, S., Jovanović, J., Gašević, D., \& Pardo, A. (2017). From prediction to impact: Evaluation of a learning analytics retention program. In Proceedings of the 7th International Conference on Learning Analytics and Knowledge (LAK '17), 13-17 March, 2017, Vancouver, BC (pp. 474-478). New York, NY: ACM. https://dx.doi.org/10.1145/3027385.3027405

D’Mello, S., Dieterle, E., \& Duckworth, A. (2017). Advanced, analytic, automated (AAA) measurement of engagement during learning. Educational Psychologist, 52(2), 104-123. https://dx.doi.org/10.1080/00461520.2017.1281747

Dodge, B., Whitmer, J., \& Frazee, J. P. (2015). Improving undergraduate student achievement in large blended courses through data-driven interventions. In Proceedings of the 5th International Conference on Learning Analytics and Knowledge (LAK '15), 16-20 March 2015, Poughkeepsie, NY (pp. 412-413). New York, NY: ACM. https://dx.doi.org/10.1145/2723576.2723657

Domínguez, C., Jaime, A., Sánchez, A., Blanco, J. M., \& Heras, J. (2016). A comparative analysis of the consistency and difference among online self-, peer-, external- and instructor-assessments: The competitive effect. Computers in Human Behavior, 60, 112-120. https://dx.doi.org/10.1016/j.chb.2016.02.061

Evans, C., Kandiko Howson, C., \& Forsythe, A. (2018). Making sense of learning gain in higher education. Higher Education Pedagogies, 3(1), 1-45. https://dx.doi.org/10.1080/23752696.2018.1508360

Ferguson, R., \& Clow, D. (2015). Examining engagement: Analysing learner subpopulations in massive open online courses (MOOCs). In Proceedings of the 5th International Conference on Learning Analytics and Knowledge (LAK '15), 1620 March 2015, Poughkeepsie, NY (pp. 51-58). New York, NY: ACM. https://dx.doi.org/10.1145/2723576.2723606

Ferguson, R., \& Clow, D. (2017). Where is the evidence? A call to action for learning analytics. In Proceedings of the 7th International Conference on Learning Analytics and Knowledge (LAK '17), 13-17 March 2017, Vancouver, BC, Canada (pp. 56-65). New York, NY: ACM. https://dx.doi.org/10.1145/3027385.3027396

Ferguson, R., Clow, D., Griffiths, D., \& Brasher, A. (2019). Moving forward with learning analytics: Expert views. Journal of Learning Analytics, 6(3), 43-59. https://dx.doi.org/10.18608/jla.2019.63.8

Gašević, D., Adesope, O., Joksimović, S., \& Kovanović, V. (2015). Externally-facilitated regulation scaffolding and role assignment to develop cognitive presence in asynchronous online discussions. The Internet and Higher Education, 24, 53-65. https://dx.doi.org/10.1016/j.iheduc.2014.09.006

Gašević, D., Dawson, S., Rogers, T., \& Gašević, D. (2016). Learning analytics should not promote one size fits all: The effects of instructional conditions in predicting academic success. Internet and Higher Education, 28, 68-84. https://dx.doi.org/10.1016/j.iheduc.2015.10.002

Gašević, D., Dawson, S., \& Siemens, G. (2015). Let's not forget: Learning analytics are about learning. TechTrends, 59(1), 64-71. https://dx.doi.org/10.1007/s11528-014-0822-x

Gašević, D., Kovanović, V., \& Joksimović, S. (2017). Piecing the learning analytics puzzle: A consolidated model of a field of research and practice. Learning: Research and Practice, 3(1), 63-78. https://dx.doi.org/10.1080/23735082.2017.1286142

Gašević, D., Kovanović, V., Joksimović, S., \& Siemens, G. (2014). Where is research on massive open online courses headed? A data analysis of the MOOC Research Initiative. The International Review of Research in Open and Distributed Learning, 15(5). https://dx.doi.org/10.19173/irrodl.v15i5.1954

Giesbers, B., Rienties, B., Tempelaar, D., \& Gijselaers, W. (2013). Investigating the relations between motivation, tool use, participation, and performance in an e-learning course using web-videoconferencing. Computers in Human Behavior, 29(1), 285-292. https://dx.doi.org/10.1016/j.chb.2012.09.005

Goggins, S., \& Xing, W. L. (2016). Building models explaining student participation behavior in asynchronous online discussion. Computers \& Education, 94, 241-251. https://dx.doi.org/10.1016/j.compedu.2015.11.002

Gunn, C., McDonald, J., Donald, L., Nichols, M., Milne, J., \& Blumenstein, M. (2017). Building an evidence base for teaching and learning design using learning analytics (Report). Wellington, New Zealand: Ako Aotearoa — The National Centre for Tertiary Teaching Excellence. Retrieved from https://ako.ac.nz/knowledge-centre/using-learninganalytics/research-report-building-an-evidence-base-for-teaching-and-learning-design-using-learning-analytics/ 
Gunnarsson, B. L., \& Alterman, R. (2012). Predicting failure: A case study in co-blogging. In Proceedings of the 2nd International Conference on Learning Analytics and Knowledge (LAK '12), 29 April-2 May 2012, Vancouver, BC, Canada (pp. 263-266). New York, NY: ACM. https://dx.doi.org/10.1145/2330601.2330665

Hattie, J. (2015). The applicability of visible learning to higher education. Scholarship of Teaching and Learning in Psychology, 1(1), 79-91. Retrieved from https://psycnet.apa.org/doi/10.1037/st10000021

Huang, T. C. K., Huang, C. H., \& Chuang, Y. T. (2016). Change discovery of learning performance in dynamic educational environments. Telematics and Informatics, 33(3), 773-792. https://dx.doi.org/10.1016/j.tele.2015.10.005

Ifenthaler, D., Adcock, A. B., Erlandson, B. E., Gosper, M., Greiff, S., \& Pirnay-Dummer, P. (2014). Challenges for education in a connected world: Digital learning, data rich environments, and computer-based assessment Introduction to the inaugural special issue of Technology, Knowledge and Learning. Technology, Knowledge and Learning, 19(1-2), 121-126. https://dx.doi.org/10.1007/s10758-014-9228-2

Jayaprakash, S. M., Moody, E. W., Lauría, E. J., Regan, J. R., \& Baron, J. D. (2014). Early alert of academically at-risk students: An open source analytics initiative. Journal of Learning Analytics, 1(1), 6-47.

https://dx.doi.org/10.18608/jla.2014.11.3

Jo, I.-H., Park, Y., Yoon, M., \& Sung, H. (2016). Evaluation of online log variables that estimate learners' time management in a Korean online learning context. International Review of Research in Open and Distance Learning, 17(1), 195-

213. https://dx.doi.org/10.19173/irrodl.v17i1.2176

Joksimović, S., Gašević, D., Kovanović, V., Riecke, B. E., \& Hatala, M. (2015). Social presence in online discussions as a process predictor of academic performance. Journal of Computer Assisted Learning, 31(6), 638-654.

https://dx.doi.org/10.1111/jcal.12107

Joksimović, S., Gašević, D., Loughin, T., Kovanović, V., \& Hatala, M. (2015). Learning at distance: Effects of interaction traces on academic achievement. Computers \& Education, 87, 204-217.

https://dx.doi.org/10.1016/j.compedu.2015.07.002

Joksimović, S., Poquet, O., Kovanović, V., Dowell, N., Mills, C., Gašević, D., \& Brooks, C. (2018). How do we model learning at scale? A systematic review of research on MOOCs. Review of Educational Research, 88(1), 43-86. https://dx.doi.org/10.3102/0034654317740335

Jovanović, J., Gašević, D., Pardo, A., Dawson, S., \& Whitelock-Wainwright, A. (2019). Introducing meaning to clicks: Towards traced-measures of self-efficacy and cognitive load. In Proceedings of the 9th International Conference on Learning Analytics \& Knowledge (LAK '19), 4-8 March 2019, Tempe, AZ (pp. 511-520). New York: ACM. https://dx.doi.org/10.1145/3303772.3303782

Kim, D., Yoon, M., Jo, I. H., \& Branch, R. M. (2018). Learning analytics to support self-regulated learning in asynchronous online courses: A case study at a women's university in South Korea. Computers and Education, 127, 233-251. https://dx.doi.org/10.1016/j.compedu.2018.08.023

Kitchenham, B., \& Charters, S. (2007). Guidelines for performing systematic literature reviews in software engineering. EBSE Technical Report v2.3. Keele, Staffs and Durham, UK: Keele University and University of Durham [Joint Report]. Retrieved from http://citeseerx.ist.psu.edu/viewdoc/summary?doi=10.1.1.117.471

Laurillard, D., Charlton, P., Craft, B., Dimakopoulos, D., Ljubojevic, D., Magoulas, G., \& Whittlestone, K. (2013). A constructionist learning environment for teachers to model learning designs. Journal of Computer Assisted Learning, 29(1), 15-30. https://dx.doi.org/10.1111/j.1365-2729.2011.00458.x

Lave, J., \& Wenger, E. (1991). Situated learning: Legitimate peripheral participation. Cambridge, UK: Cambridge University Press. https://dx.doi.org/10.1017/CBO9780511815355

Li, K. C., Lam, H. K., \& Lam, S. S. (2015). A review of learning analytics in educational research. In J. Lam, K. Ng, S. Cheung, T. Wong, K. Li, \& F. Wang (Eds.), Technology in education. Technology-mediated proactive learning. ICTE 2015. Communications in Computer and Information Science, vol. 559 (pp. 173-184). New York, NY: Springer. https://dx.doi.org/10.1007/978-3-662-48978-9 17

Lockyer, L., Heathcote, E., \& Dawson, S. (2013). Informing pedagogical action: Aligning learning analytics with learning design. American Behavioral Scientist, 57(10), 1439-1459. https://dx.doi.org/10.1177/0002764213479367.

Macfadyen, L., \& Dawson, S. (2010). Mining LMS data to develop an "early warning system" for educators: A proof of concept. Computers \& Education, 54(2), 588-599. https://dx.doi.org/10.1016/j.compedu.2009.09.008

Mangaroska, K., \& Giannakos, M. (2019). Learning analytics for learning design: A systematic literature review of analytics-driven design to enhance learning. IEEE Transactions on Learning Technologies, 12(4), 516-534. http://dx.doi.org/10.1109/TLT.2018.2868673

Martin, F., \& Whitmer, J. C. (2016). Applying learning analytics to investigate timed release in online learning. Technology, Knowledge and Learning, 21(1), 59-74. https://dx.doi.org/10.1007/s10758-015-9261-9 
Martínez-Muñoz, G., \& Pulido, E. (2015). Using a SPOC to flip the classroom. Paper presented at the IEEE Global Engineering Education Conference, EDUCON, 18-20 March 2015, Tallinn, Estonia. Retrieved from https://ieeexplore.ieee.org/document/7096007

McConnell, M. (2019). Using OnTask in a large first year Commercial Law course on a Bachelor of Commerce degree. In A. Pardo, D. Y. T. Liu, L. Vigentini, \& M. Blumenstein (Eds.), Scaling personalised student communication Current initiatives and future directions (Workshop). Australian Learning Analytics Summer Institute (ALASI), University of Wollongong, NSW. Retrieved from https://www.ontasklearning.org/scaling-personalised-studentcommunication-current-initiatives-future-directions/

Milliron, M. D., Malcolm, L., \& Kil, D. (2014). Insight and action analytics: Three case studies to consider. Research \& Practice in Assessment, 9(Winter), 72-82. Retrieved from http://www.rpajournal.com/dev/wpcontent/uploads/2014/10/A7.pdf

Mor, Y., Ferguson, R., \& Wasson, B. (2015). Learning design, teacher inquiry into student learning and learning analytics: A call for action. British Journal of Educational Technology, 46(2), 221-229. https://dx.doi.org/10.1111/bjet.12273

Muuro, M. E., Oboko, R., \& Wagacha, P. (2016). Evaluation of intelligent grouping based on learners' collaboration competence level in online collaborative learning environment. International Review of Research in Open and Distance Learning, 17(2). https://dx.doi.org/10.19173/irrodl.v17i2.2066

Nguyen, Q., Rienties, B., Toetenel, L., Ferguson, R., \& Whitelock, D. (2017). Examining the designs of computer-based assessment and its impact on student engagement, satisfaction, and pass rates. Computers in Human Behavior, 76, 703-714. https://dx.doi.org/10.1016/j.chb.2017.03.028

Ott, C., Robins, A., Haden, P., \& Shephard, K. (2015). Illustrating performance indicators and course characteristics to support students' self-regulated learning in CS1. Computer Science Education, 25(2), 174-198. https://dx.doi.org/10.1080/08993408.2015.1033129

Papamitsiou, Z., \& Economides, A. A. (2014). Learning analytics and educational data mining in practice: A systematic literature review of empirical evidence. Journal of Educational Technology \& Society, 17(4), 49-64. Retrieved from https://www.jstor.org/stable/10.2307/jeductechsoci.17.4.49

Pardo, A., Bartimote-Aufflick, K., Buckingham Shum, S., Dawson, S., Gao, J., Gašević, D., ..., Vigentini, L. (2018). OnTask: Delivering data-informed personalized learning support actions. Journal of Learning Analytics, 5(3), 235249. https://dx.doi.org/10.18608/jla.2018.53.15

Pardo, A., Han, F., \& Ellis, R. A. (2017). Combining university student self-regulated learning indicators and engagement with online learning events to predict academic performance. IEEE Transactions on Learning Technologies, 10(1), 82-92. https://dx.doi.org/10.1109/TLT.2016.2639508

Pardo, A., Jovanović, J., Dawson, S., Gašević, D., \& Mirriahi, N. (2019). Using learning analytics to scale the provision of personalised feedback. British Journal of Educational Technology, 50(1), 128-138. https://doi.org/10.1111/bjet.12592

Redecker, C., Leis, M., Leendertse, M., Punie, Y., Gijsbers, G., Kirschner, P. A., ..., Hoogveld, B. (2011). The future of learning: Preparing for change. Seville, Spain: JRC IPTS. Retrieved from https://www.researchgate.net/publication/256461836 The Future of Learning Preparing for Change

Reimann, P. (2016). Connecting learning analytics with learning research: The role of design-based research. Learning: Research and Practice, 2(2), 130-142. https://dx.doi.org/10.1080/23735082.2016.1210198

Reschly, A. L., \& Christenson, S. L. (2012). Jingle, jangle, and conceptual haziness: Evolution and future directions of the engagement construct. In S. Christenson, A. Reschly, \& C. Wylie (Eds.), Handbook of research on student engagement (pp. 3-19). Boston, MA: Springer. https://dx.doi.org/10.1007/978-1-4614-2018-7_1

Rienties, B., Boroowa, A., Cross, S., Kubiak, C., Mayles, K., \& Murphy, S. (2016). Analytics4Action Evaluation Framework: A review of evidence-based learning analytics interventions at the Open University UK. Journal of Interactive Media in Education, 2016(1). http://dx.doi.org/10.5334/jime.394

Rienties, B., \& Alden, B. (2014). Emotions used in learning analytics: A state-of-the-art review. Measuring and Understanding Learner Emotions: Evidence and Prospects (2). LACE Project. Retrieved from https://oro.open.ac.uk/72634/1/LACE_emotions_05 12 2014\%20copy.pdf

Rienties, B., \& Toetenel, L. (2016). The impact of learning design on student behaviour, satisfaction and performance: A cross-institutional comparison across 151 modules. Computers in Human Behavior, 60, 333-341. https://dx.doi.org/10.1016/j.chb.2016.02.074

Rienties, B., Toetenel, L., \& Bryan, A. (2015). "Scaling up" learning design: Impact of learning design activities on LMS behavior and performance. In Proceedings of the 5th International Conference on Learning Analytics and Knowledge (LAK ’15), 16-20 March 2015, Poughkeepsie, NY (pp. 315-319). New York, NY: ACM.

https://dx.doi.org/10.1145/2723576.2723600

ISSN 1929-7750 (online). The Journal of Learning Analytics works under a Creative Commons License, Attribution - NonCommercial-NoDerivs 3.0 Unported (CC BY-NC-ND 3.0) 
Romero, C., López, M. I., Luna, J. M., \& Ventura, S. (2013). Predicting students' final performance from participation in online discussion forums. Computers and Education, 68, 458-472. https://dx.doi.org/10.1016/j.compedu.2013.06.009

Romero-Zaldivar, V. A., Pardo, A., Burgos, D., \& Delgado Kloos, C. (2012). Monitoring student progress using virtual appliances: A case study. Computers and Education, 58(4), 1058-1067. https://dx.doi.org/10.1016/j.compedu.2011.12.003

Rosenthal, R., \& DiMatteo, M. R. (2001). Meta-analysis: Recent developments in quantitative methods for literature reviews. Annual Review of Psychology, 52(1), 59-82. https://dx.doi.org/10.1146/annurev.psych.52.1.59

Rubio, F., Thomas, J. M., \& Li, Q. (2018). The role of teaching presence and student participation in Spanish blended courses. Computer Assisted Language Learning, 31(3), 226-250. https://dx.doi.org/10.1080/09588221.2017.1372481

Schneider, M., \& Preckel, F. (2017). Variables associated with achievement in higher education: A systematic review of meta-analyses. Psychological Bulletin, 143(6), 565-600. Retrieved from https://psycnet.apa.org/doi/10.1037/bul0000098

Schumacher, C., \& Ifenthaler, D. (2018). The importance of students' motivational dispositions for designing learning analytics. Journal of Computing in Higher Education, 30(3), 599-619. https://dx.doi.org/10.1007/s12528-018-9188-y

Sønderlund, A. L., Hughes, E., \& Smith, J. (2018). The efficacy of learning analytics interventions in higher education: A systematic review. British Journal of Educational Technology, 50(5), 2594-2618. https://dx.doi.org/10.1111/bjet.12720

Tabuenca, B., Kalz, M., Drachsler, H., \& Specht, M. (2015). Time will tell: The role of mobile learning analytics in selfregulated learning. Computers and Education, 89, 53-74. https://dx.doi.org/10.1016/j.compedu.2015.08.004

Tempelaar, D., Rienties, B., \& Giesbers, B. (2015). In search for the most informative data for feedback generation: Learning analytics in a data-rich context. Computers in Human Behavior, 47, 157-167.

https://dx.doi.org/10.1016/j.chb.2014.05.038

Tempelaar, D., Rienties, B., Mittelmeier, J., \& Nguyen, Q. (2018). Student profiling in a dispositional learning analytics application using formative assessment. Computers in Human Behavior, 78, 408-420. https://dx.doi.org/10.1016/j.chb.2017.08.010

Vermunt, J. D. (1996). Metacognitive, cognitive and affective aspects of learning styles and strategies: A phenomenographic analysis. Higher Education, 31(1), 25-50. https://dx.doi.org/10.1007/BF00129106

Vermunt, J. D., Ilie, S., \& Vignoles, A. (2018). Building the foundations for measuring learning gain in higher education: A conceptual framework and measurement instrument. Higher Education Pedagogies, 3(1), 266-301. https://dx.doi.org/10.1080/23752696.2018.1484672

Viberg, O., Hatakka, M., Bälter, O., \& Mavroudi, A. (2018). The current landscape of learning analytics in higher education. Computers in Human Behavior, 89, 98-110. https://dx.doi.org/10.1016/j.chb.2018.07.027

West, D., Huijser, H., \& Heath, D. (2018). Blurring the boundaries: Developing leadership in learning analytics. In J. Lodge, J. C. Horvath, \& L. Corrin (Eds.), Learning analytics in the classroom: Translating learning analytics research for teachers (pp. 267-283). London, UK: Routledge. https://dx.doi.org/10.4324/9781351113038-16

You, J. W. (2015). Examining the effect of academic procrastination on achievement using LMS data in e-learning. Journal of Educational Technology \& Society, 18(3), 64-74. Retrieved from https://www.jstor.org/stable/10.2307/jeductechsoci.18.3.64

Yu, T., \& Jo, I. H. (2014). Educational technology approach toward learning analytics: Relationship between student online behavior and learning performance in higher education. In Proceedings of the 4th International Conference on Learning Analytics and Knowledge (LAK '14), 24-28 March 2014, Indianapolis, IN (pp. 269-270). New York, NY: ACM https://dx.doi.org/10.1145/2567574.2567594

Zhang, J.-H., Zou, L.-c., Miao, J.-j., Zhang, Y.-X., Hwang, G.-J., \& Zhu, Y. (2019). An individualized intervention approach to improving university students' learning performance and interactive behaviors in a blended learning environment. Interactive Learning Environments, 28(2), 231-245. https://dx.doi.org/10.1080/10494820.2019.1636078

Zimmerman, B. J. (2002). Becoming a self-regulated learner: An overview. Theory into Practice, 41(2), 64-70. https://dx.doi.org/10.1207/s15430421tip4102_2 


\section{APPENDIX A: SUPPLEMENTARY MATERIAL}

Table S1. Quality check list modelled on Kitchenham and Charters (2007, pp. 25-27)

\begin{tabular}{l|l}
\hline Question & Yes \\
\hline Are the aims clearly stated? & \\
Control and comparison group (if experimental) & \\
Variables adequately measured and fully defined & \\
Measures relevant for answering the RQs & \\
Sources of bias & \\
\hline Data collection explained & \\
Dropouts or exclusions & \\
Did untoward events occur during the study? & \\
Are potential confounders/biases controlled for? & \\
\hline Data analysis methods appropriate & \\
Dropouts and outliers accounted for & \\
Subjects explained & \\
Data types explained & \\
Tables/graphs consistent & \\
Evidence of effect size and model precision/recall & \\
\hline Are the study questions answered? & \\
Is practical significance of the findings discussed? & \\
Are LA data implicated by LD and teaching practice? & \\
\hline
\end{tabular}

Table S2. Data extraction form based on Kitchenham and Charters (2007, pp. 30-31)

\begin{tabular}{l|l}
\hline \multicolumn{1}{c|}{ Data Item } & $\begin{array}{c}\text { Description, } \\
\text { value, Yes/No, } \\
\text { or comment }\end{array}$ \\
\hline Author(s), year of publication & \\
\hline Type of publication & \\
\hline Peer reviewed (yes/no) & \\
\hline Context (e.g., UG, PG, MOOC; discipline) & \\
\hline Research rational/issue & \\
\hline Scope (research question, hypothesis, goal) & \\
\hline Learning design(s) used & \\
\hline Learning outcomes - proposed & \\
\hline Learning outcomes - measured & \\
\hline Sampling (e.g. randomized, convenience, size) & \\
\hline If bias, how was it controlled? & \\
\hline LA data source and units measured (e.g. quizzes, grades, discussions, activity) & \\
\hline Variables included in data analysis & \\
\hline Transformation of LA data and why (e.g., coding schemes, normalization, \\
controlling for covariates) & \\
\hline Which statistical/analysis tools were used? & \\
\hline How were accuracy and effectiveness measured (e.g., $R^{2}$, odds ratio, risk, $\left.r\right)$ & \\
\hline If several data analysis techniques were used, which was most accurate? & \\
\hline Did the study result in evidence-based practitioner guidelines? (Yes/No; summary) & \\
\hline Summary of paper & \\
\hline Decision to include/exclude in review (Yes/No; give reason) & \\
\hline
\end{tabular}


Table S3. Characteristics and Extracted Effects with Recalculated Cohen's $d$ and Pearson $r$ for 25 Selected Studies Identified in Phase One of Review

\begin{tabular}{|c|c|c|c|c|c|c|c|c|}
\hline Authors & $\begin{array}{l}\text { Setting } \\
\text { Country }\end{array}$ & $\begin{array}{l}\text { LD element } \\
\text { Objective }\end{array}$ & $\begin{array}{l}\text { Data } \\
\text { Sources }\end{array}$ & $\begin{array}{l}\text { Study } \\
\text { Design }\end{array}$ & $\begin{array}{l}\text { Main effects and } \\
\text { codes for outcome }\end{array}$ & $\begin{array}{l}\text { Effects on LP, } \\
\text { CO, OP } \\
\text { Cohen's } d\end{array}$ & $r$ & $\begin{array}{l}\text { Coding of } \\
\text { gains for } \\
\text { Figure } 2 \\
\end{array}$ \\
\hline \multicolumn{9}{|c|}{ Coding for Ways of learning — Collaboration (social learning and collective efficacy) } \\
\hline $\begin{array}{l}\text { Goggins \& } \\
\text { Xing, } 2016\end{array}$ & $\begin{array}{l}\text { ON } \\
\text { USA }\end{array}$ & $\begin{array}{l}\text { Tasks: } \\
\text { Social } \\
\text { cognition }\end{array}$ & $\begin{array}{l}\text { Questionnaire } \\
\text { aligned with } \\
\text { social cognitive } \\
\text { theory (Likert } \\
\text { scales); student } \\
\text { activity logs }\end{array}$ & $\begin{array}{l}\mathrm{S} \\
\text { Conv } \\
N=24\end{array}$ & $\begin{array}{l}\text { Reading time RT ( } 1) \text { and posting } \\
\text { time PT (2) better predict grades } \\
(\mathrm{LP})(r=0.45) \text { compared to reading } \\
\text { action RA ( } 3) \text { and posting action } \\
\text { PA (4), } r=0.35 \text {. The impact of RT } \\
\text { on LP is mediated by students' } \\
\text { social online ability SA (5) and } \\
\text { collective efficacy CE }(6) \text {. }\end{array}$ & $\begin{array}{l}\text { (1) } \mathrm{RT} \Rightarrow \text { LP: } 2.687 * * * \\
\text { (2) } \mathrm{PT} \Rightarrow \text { LP: } 1.364 * * \\
\text { (3) RA } \Rightarrow \text { LP: } 1.972 * * * \\
\text { (4) } \mathrm{PA} \Rightarrow \text { LP: } 0.960 * \\
\text { (5) RT } \Rightarrow \text { LP, SA } \\
\text { adjusted }(B=0.38): \geq \\
0.713^{*} \\
\text { (6) RT } \Rightarrow \text { LP, CE } \\
\text { adjusted }(\mathrm{B}=0.52): \geq \\
1.079 * *\end{array}$ & $\begin{array}{l}0.802 \\
0.563 \\
0.702 \\
0.433 \\
\geq 0.336 \\
\geq 0.475\end{array}$ & $\begin{array}{l}\text { SC } \\
\text { SC } \\
\text { SC } \\
\text { SC } \\
\\
\text { NS } \\
\text { NS }\end{array}$ \\
\hline $\begin{array}{l}\text { Gašević, } \\
\text { Adesope, et } \\
\text { al., } 2015\end{array}$ & $\begin{array}{l}\mathrm{ON} \\
\mathrm{CAN}\end{array}$ & $\begin{array}{l}\text { Supports: } \\
\text { Cognitive } \\
\text { presence }\end{array}$ & $\begin{array}{l}\text { Content of } \\
\text { discussion } \\
\text { posts (e.g. } \\
\text { triggering } \\
\text { event, } \\
\text { exploration, } \\
\text { integration, } \\
\text { resolution); } \\
\text { total number of } \\
\text { posts }\end{array}$ & $\begin{array}{l}\mathrm{S} \\
\operatorname{Exp} \\
N=82\end{array}$ & $\begin{array}{l}\text { Role assignment (RA) and } \\
\text { scaffolded discussions (SCD) } \\
\text { increase integration messages as } \\
\text { proxy for cognitive processes (OP, } \\
\text { 1). RA and EPG affects cognitive } \\
\text { presence (OP) via a decrease in } \\
\text { discussion triggering events }(2,3) .\end{array}$ & $\begin{array}{l}\text { (1) } \mathrm{RA}+\mathrm{SCD} \Rightarrow \mathrm{OP}: \\
2.470 \\
\text { (2) } \mathrm{RA} \Rightarrow \mathrm{OP}: 0.845^{* * *} \\
\text { (3) } \mathrm{EPG} \Rightarrow \text { OP: } 0.508 *\end{array}$ & $\begin{array}{l}0.777 \\
0.389 \\
0.246\end{array}$ & $\begin{array}{l}\mathrm{MC} \\
\mathrm{MC} \\
\mathrm{MC}\end{array}$ \\
\hline $\begin{array}{l}\text { Romero et } \\
\text { al., } 2013\end{array}$ & $\begin{array}{l}\text { BL } \\
\text { SPAIN }\end{array}$ & $\begin{array}{l}\text { Tasks: } \\
\text { Pass/fail } \\
\text { prediction }\end{array}$ & $\begin{array}{l}\text { Number of } \\
\text { messages read } \\
\text { and posted, } \\
\text { time; message } \\
\text { content as } \\
\text { proxy for } \\
\text { cognition; } \\
\text { social network } \\
\text { degree of } \\
\text { centrality and } \\
\text { prestige; final } \\
\text { mark }\end{array}$ & $\begin{array}{l}\mathrm{M} \\
\text { Conv } \\
N=114\end{array}$ & $\begin{array}{l}\text { Discussion participation, e.g. } \\
\text { number of messages and sentences, } \\
\text { students' social network status } \\
\text { (centrality/ prestige) combined with } \\
\text { quality of message (content) as } \\
\text { indicator of cognition (OP) can } \\
\text { predict student outcome (JRiP } \\
\text { model). }\end{array}$ & $\begin{array}{l}\text { Messages \& Sentences } \\
\Rightarrow \text { OP: } 2.220 \\
\text { Centrality \& Messages } \\
\Rightarrow \text { OP: } 1.955 \\
\text { Content \& Centrality } \Rightarrow \\
\text { OP: } 1.297 \\
\text { Time \& Content } \Rightarrow \text { OP: } \\
0.527 \\
\text { Threads \& Time } \Rightarrow \text { OP: } \\
0.032 \\
\text { Pass/fail prediction } \\
\text { accuracy (JRiP): } \\
77 \% \text { at midterm } \\
90 \% \text { by end of term }\end{array}$ & $\begin{array}{l}0.743 \\
0.699 \\
0.544 \\
0.255 \\
0.016\end{array}$ & $\begin{array}{l}\mathrm{SC} \\
\mathrm{SC} \\
\mathrm{SC} \\
\mathrm{SC} \\
\mathrm{SC} \\
\\
\mathrm{NS} \\
\mathrm{NS}\end{array}$ \\
\hline $\begin{array}{l}\text { Gunnarsson } \\
\text { \& Alterman, } \\
2012\end{array}$ & $\begin{array}{l}\text { BL } \\
\text { USA }\end{array}$ & $\begin{array}{l}\text { Supports: } \\
\text { Enhancing } \\
\text { participation }\end{array}$ & $\begin{array}{l}\text { Number of } \\
\text { posts read; } \\
\text { grades }\end{array}$ & $\begin{array}{l}\mathrm{S} \\
\text { Conv } \\
N=50\end{array}$ & $\begin{array}{l}\text { Student's blog contribution } \\
\text { positively correlates with } \\
\text { assignment grade (LP, 1). Prior } \\
\text { grade (2) and participation (3) from } \\
\text { three prior homework tasks are } \\
\text { predictive of students' current } \\
\text { course outcome (CO). }\end{array}$ & $\begin{array}{l}\text { (1) Blog participation } \Rightarrow \\
\text { LP: } 1.960 * * * \\
\text { (2) Prior grade } \Rightarrow \mathrm{CO} \text { : } \\
0.697 * * \\
\text { (3) Prior participation } \Rightarrow \\
\text { CO: } 0.416^{* *}\end{array}$ & $\begin{array}{l}0.700 \\
0.329 \\
0.204\end{array}$ & $\begin{array}{l}\mathrm{SC} \\
\mathrm{SC} \\
\mathrm{SC}\end{array}$ \\
\hline $\begin{array}{l}\text { Casquero et } \\
\text { al., } 2016\end{array}$ & $\begin{array}{l}\text { ON } \\
\text { SPAIN }\end{array}$ & $\begin{array}{l}\text { Supports: } \\
\text { Social } \\
\text { network } \\
\text { reach }\end{array}$ & $\begin{array}{l}\text { Moodle } \\
\text { analytics; } \\
\text { iGoogle, } \\
\text { Google Groups, } \\
\text { FriendFeed, } \\
\text { OpenID using } \\
\text { variable } \\
\text { network reach } \\
\text { interaction data } \\
\text { in Python }\end{array}$ & $\begin{array}{l}\mathrm{S} \\
\operatorname{Exp} \\
N=120\end{array}$ & $\begin{array}{l}\text { Grades (LP) improve with students' } \\
\text { personal network (egonet) size in } \\
\text { both personal (PLE) and virtual } \\
\text { learning environments (VLE; } 1,2 \text { ). } \\
\text { Students with a PLE develop larger } \\
\text { personal networks (3). No } \\
\text { significant difference in grades } \\
\text { between VLE and PLE usage (4). }\end{array}$ & $\begin{array}{l}\text { (1) Egonet (personal) } \Rightarrow \\
\text { LP: } 1.955^{* * *} \\
\text { (2) Egonet (virtual) } \Rightarrow \\
\text { LP: } 1.190^{* * *} \\
\text { (3) Egonet PLE > VLE: } \\
\text { 1.842*** } \\
\text { (4) Grade in VLE vs. } \\
\text { PLE: } 0.217\end{array}$ & $\begin{array}{l}0.699 \\
0.511 \\
0.762 \\
0.109\end{array}$ & $\begin{array}{l}\mathrm{SC} \\
\mathrm{SC} \\
\mathrm{NS} \\
\mathrm{NS}\end{array}$ \\
\hline $\begin{array}{l}\text { Giesbers et } \\
\text { al., } 2013\end{array}$ & $\begin{array}{l}\mathrm{ON} \\
\mathrm{NL}\end{array}$ & $\begin{array}{l}\text { Resources: } \\
\text { e-design } \\
\text { guidelines }\end{array}$ & $\begin{array}{l}\text { Academic } \\
\text { Motivation } \\
\text { Scale (AMS) } \\
\text { survey (Likert } \\
\text { scales); video- } \\
\text { conference tool } \\
\text { usage }\end{array}$ & $\begin{array}{l}\mathrm{M} \\
\text { Conv } \\
N=110\end{array}$ & $\begin{array}{l}\text { Student participation in web- } \\
\text { videoconferencing relates } \\
\text { positively to final exam grade (LP, } \\
\text { 1). Students with higher intrinsic } \\
\text { motivation to accomplish (IMTA) } \\
\text { have higher participation rates (2) } \\
\text { impacting on grade ( } 3 \text {; trending } p< \\
0.1) \text {. }\end{array}$ & $\begin{array}{l}\text { (1) Participation } \Rightarrow \text { LP: } \\
1.548 * * \\
\text { (2) IMTA } \times \\
\text { Participation } \Rightarrow \text { LP: } \\
0.652 * * \\
\text { (3) IMTA } \Rightarrow \text { LP: } 0.367\end{array}$ & $\begin{array}{l}0.612 \\
0.309 \\
0.181\end{array}$ & $\begin{array}{l}\mathrm{SC} \\
\mathrm{MC} \\
\mathrm{MC}\end{array}$ \\
\hline
\end{tabular}


JOURNAL OF LEARNING ANALYTICS

\begin{tabular}{|c|c|c|c|c|c|c|c|c|}
\hline $\begin{array}{l}\text { Domínguez } \\
\text { et al., } 2016\end{array}$ & $\begin{array}{l}\text { BL } \\
\text { SPAIN }\end{array}$ & $\begin{array}{l}\text { Tasks: } \\
\text { formative } \\
\text { assessment } \\
\text { methods }\end{array}$ & $\begin{array}{l}\text { Measures } \\
\text { (Likert scales) } \\
\text { of students' } \\
\text { learning task } \\
\text { products } \\
\text { (assessment } \\
\text { outcomes) }\end{array}$ & $\begin{array}{l}\mathrm{S} \\
\text { Conv } \\
N=97\end{array}$ & $\begin{array}{l}\text { Designs including self- (S), peer } \\
\text { (P), external (E) assessment } \\
\text { improve grades (LP, 1). High-grade } \\
\text { students assess own work higher } \\
\text { (2) compared to lower performing } \\
\text { students (3). }\end{array}$ & $\begin{array}{l}\text { (1) Peer/self assessment } \\
\Rightarrow \text { LP: } 0.383 * \\
\text { Competency-based } \\
\text { differences: } \\
\text { (2) High-grade (S vs. E): } \\
0.641^{*} \\
\text { (3) Low-grade (S vs. E): } \\
0.363 * * *\end{array}$ & $\begin{array}{l}0.188 \\
0.305 \\
0.178\end{array}$ & $\begin{array}{l}\text { NS } \\
\text { NS }\end{array}$ \\
\hline $\begin{array}{l}\text { Muuro et al., } \\
2016\end{array}$ & $\begin{array}{l}\text { BL } \\
\text { KENYA }\end{array}$ & $\begin{array}{l}\text { Tasks: } \\
\text { Group effects }\end{array}$ & $\begin{array}{l}\text { Moodle } \\
\text { analytics (e.g. } \\
\text { number of } \\
\text { posts/replies, } \\
\text { forum ratings); } \\
\text { grades; pre- and } \\
\text { post-test survey } \\
\text { responses }\end{array}$ & $\begin{array}{l}\mathrm{S} \\
\text { Rand } \\
N=90\end{array}$ & $\begin{array}{l}\text { Student group formation (GPA- } \\
\text { based, random, algorithm-based) } \\
\text { influences group leadership } \\
\text { (cognitive presence coded as OP), } \\
\text { but not performance and } \\
\text { satisfaction. }\end{array}$ & $\begin{array}{l}\text { Group formation } \\
\text { method } \Rightarrow \text { OP } \\
\text { (leadership } \\
\text { effectiveness): } 0.443 *\end{array}$ & 0.216 & $\mathrm{SC}$ \\
\hline $\begin{array}{l}\text { Joksimović, } \\
\text { Gašević, } \\
\text { Kovanović et } \\
\text { al., } 2015\end{array}$ & $\begin{array}{l}\text { ON } \\
\text { CANADA }\end{array}$ & $\begin{array}{l}\text { Supports: } \\
\text { Social } \\
\text { presence }\end{array}$ & $\begin{array}{l}\text { Content } \\
\text { analysis of } \\
\text { discussion } \\
\text { posts as social } \\
\text { presence } \\
\text { indicators; final } \\
\text { grades }\end{array}$ & $\begin{array}{l}\mathrm{S} \\
\operatorname{Exp} \\
N=81\end{array}$ & $\begin{array}{l}\text { Continuing a thread/ask questions } \\
\text { (content) positively impacts final } \\
\text { grade (LP, 1); posts expressing } \\
\text { appreciation or complimenting } \\
\text { others (affect) are negative } \\
\text { predictors (2). Scaffolded } \\
\text { discussions produce higher level of } \\
\text { social presence impacting on grade } \\
\text { (3) compared to no scaffold (4). }\end{array}$ & $\begin{array}{l}\text { (1) Content of post } \Rightarrow \\
\text { LP: } 0.127^{* *} \\
\text { (2) Affect in post: } \\
-0.079^{*} \\
\text { (3) Social presence } \\
\text { (guided discussion) } \Rightarrow \\
\text { LP: } 0.115^{* *} \\
\text { (4) Social presence } \\
\text { (non-guided) } \Rightarrow \text { LP: } \\
0.026\end{array}$ & $\begin{array}{l}0.063 \\
-0.039 \\
0.058 \\
0.013\end{array}$ & $\begin{array}{l}\text { SC } \\
\text { A } \\
\text { SC } \\
\text { SC }\end{array}$ \\
\hline
\end{tabular}

Coding for Ways of Learning — Independent Learners (Self-Regulation and Real-Life Learning)

$\begin{array}{lll}\text { Blikstein,. et } & \text { F2F } & \text { Tasks: } \\ \text { al., } 2014 & \text { USA } & \text { learning }\end{array}$

process
Size, frequency $\mathrm{S}$ to $\mathrm{L} \quad$ Code change pattern (CCP) in of online code Conv update; number $N=346$ of lines and characters added, deleted, modified

\begin{tabular}{lllll}
\hline Romero- & F2F & Tasks: & Student usage & S \\
Zaldivar et & SPAIN & learning & data, & Conv \\
al., 2012 & & process & $\begin{array}{l}\text { programming } \\
\text { tasks data; final } \\
\text { grades }\end{array}$ & $N=79$ \\
& & &
\end{tabular}

Munoz \& BL
Pulido, 2015 SPAIN computing positively affects

outcome $(p=0.18)$ while code size

changes "tinkering" (CSZ) had no

effect (2). Coding trajectories can

predict midterm scores (3).

Resources:
design
validation

validation

\begin{tabular}{ll|}
$\begin{array}{l}\text { Small private } \\
\text { online course }\end{array}$ & Exp \\
(SPOC) data: & $N=90$ \\
access, time & \\
spent; test & \\
results and & \\
marks; student & \\
satisfaction & \\
$\begin{array}{l}\text { Static and } \\
\text { dynamic LMS }\end{array}$ & $\mathrm{L}$ Rand \\
log data: total & $N=$ \\
number of & 21,803 \\
visits, time & \\
spent in LMS & \\
$\begin{array}{l}\text { LMS log data; } \\
\text { procrastination }\end{array}$ & L Conv \\
indicators as & $N=569$ \\
failure of self- \\
regulated \\
$\begin{array}{l}\text { learning, e.g. } \\
\text { delays in }\end{array}$ \\
$\begin{array}{l}\text { scheduled } \\
\text { study, late } \\
\text { submissions }\end{array}$ \\
\end{tabular}

$\begin{array}{lll}\text { (1) } \mathrm{CCP} \Rightarrow \text { LP: } 1.606 & 0.626 & \mathrm{C} \\ \text { (2) } \mathrm{CSZ} \Rightarrow \text { LP: } 0.008 & 0.004 & \mathrm{C} \\ \text { (3) Midterm score } & 0.179 & \text { NS }\end{array}$

differences: $0.365^{*}$ C
NS
Programming tasks (WorkTime) combined with tool use (Profiler) impacts final grade (LP, 1). Work time (2) impacts grade and is trending for profiler tool use (3) and discussion participation (4).

$\begin{array}{lll}\text { (1) WorkTime \& tool } & 0.467 & \text { C } \\ \text { use } \Rightarrow \text { LP: } 1.054^{* *} & 0.317 & \text { C } \\ \text { (2) WorkTime } \Rightarrow \text { LP: } & 0.212 & \text { C } \\ 0.669^{* *} & 0.198 & \text { SC }\end{array}$

(3) Tool use $\Rightarrow$ LP:

0.433

(4) Discussion

participation $\Rightarrow$ LP: 0.404

Video use vs. other resource use $\quad$ (1) Video use $\Rightarrow$ LP: affects marks (1); SPOC-supported $0.723 * *$

teaching positively affects retention (CO) by $5.7 \%$ (2) and improves overall grades by $5.4 \%(\mathrm{LP}, 3)$, both trending.

LDs with high proportion of

assimilative learning tasks

negatively impact completion and

pass rates $(\mathrm{CO})$

Online absence (1) and late

submission (2) negatively impact

final score (LP). Predictability of

academic achievement is possible

as early as week $4(3,4)$.
(2) $\mathrm{SPOC}$

(3) $\mathrm{SPOC} \Rightarrow$ LP: 0.117

$\mathrm{LD}$ (assimilative) $\Rightarrow \quad-0.326 \quad \mathrm{C}$

$$
\text { CO: }-0.690^{*}
$$

$0.340 \quad \mathrm{C}$

$0.119 \quad \mathrm{C}$

$0.058 \mathrm{C}$

C
C


JOURNAL OF LEARNING ANALYTICS

\begin{tabular}{|c|c|c|c|c|c|c|c|c|}
\hline $\begin{array}{l}\text { Yu \& Jo, } \\
2014\end{array}$ & $\begin{array}{l}\text { F2F } \\
\text { KOREA }\end{array}$ & $\begin{array}{l}\text { Tasks: } \\
\text { self- } \\
\text { regulation }\end{array}$ & $\begin{array}{l}\text { LMS logs: total } \\
\text { login \& time; } \\
\text { regularity of } \\
\text { learning, } \\
\text { number of } \\
\text { downloads, } \\
\text { final grade, } \\
\text { interactions }\end{array}$ & $\begin{array}{l}\mathrm{S} \\
\text { Conv } \\
N=84\end{array}$ & $\begin{array}{l}\text { LMS indicators total study time } \\
\text { (ST), peer interaction (PI) } \\
\text { positively impact grade (LP), while } \\
\text { total logins (LG) and student- } \\
\text { instructor interactions (INT) show } \\
\text { negative effects on LP. }\end{array}$ & $\begin{array}{l}\text { (1) } \mathrm{ST} \Rightarrow \text { LP: } 0.463^{*} \\
\text { (2) PI } \Rightarrow \text { LP: } 0.614 * * \\
\text { (3) LG } \Rightarrow \text { LP: }-0.215 \\
\text { (4) INT } \Rightarrow \text { LP: }-0.075\end{array}$ & $\begin{array}{l}0.226 \\
0.293 \\
-0.107 \\
-0.038\end{array}$ & $\begin{array}{l}\mathrm{MC} \\
\mathrm{MC} \\
\mathrm{MC} \\
\mathrm{A}\end{array}$ \\
\hline $\begin{array}{l}\text { Jo et al., } \\
2016\end{array}$ & $\begin{array}{l}\text { ON } \\
\text { KOREA }\end{array}$ & $\begin{array}{l}\text { Resources: } \\
\text { self- } \\
\text { regulation }\end{array}$ & $\begin{array}{l}\text { Moodle activity } \\
\text { data; Time and } \\
\text { Study } \\
\text { Environment } \\
\text { Management } \\
\text { (TSEM) survey } \\
\text { (Likert scores) }\end{array}$ & $\begin{array}{l}\mathrm{M} \\
\text { Conv } \\
N=128\end{array}$ & $\begin{array}{l}\text { Psychological factors involved in } \\
\text { time management impact online } \\
\text { behaviour coded as OP (1) but not } \\
\text { final mark (LP, in 2). LMS activity } \\
\text { influences final mark (3), while TM } \\
\text { is mediated by online behaviour, } \\
\text { indirectly impacting outcome (4). }\end{array}$ & $\begin{array}{l}\text { Direct effects: } \\
\text { (1) TM } \Rightarrow \text { OP: } 0.299 * \\
\text { (2) TM } \Rightarrow \text { LP: } 0.179 \\
\text { (3) LMS activity } \Rightarrow \text { LP: } \\
0.299^{*} \\
\text { Indirect effects: } \\
\text { (4) Online behaviour } \Rightarrow \\
\text { TSEM and LP: } \\
0.578^{* * *}\end{array}$ & $\begin{array}{l}0.148 \\
0.089 \\
0.148 \\
0.278\end{array}$ & $\begin{array}{l}\text { MC } \\
\text { MC } \\
\text { MC } \\
\text { NS }\end{array}$ \\
\hline $\begin{array}{l}\text { Joksimović, } \\
\text { Gasević, } \\
\text { Loughin, et } \\
\text { al., } 2015\end{array}$ & $\begin{array}{l}\mathrm{ON} \\
\mathrm{CANADA}\end{array}$ & $\begin{array}{l}\text { Resources: } \\
\text { design } \\
\text { validation }\end{array}$ & $\begin{array}{l}\text { Moodle log } \\
\text { data: total } \\
\text { count; total } \\
\text { time spent; } \\
\text { student } \\
\text { interactions } \\
\text { with other } \\
\text { students, } \\
\text { content, } \\
\text { teachers, and } \\
\text { systems }\end{array}$ & $\begin{array}{l}\mathrm{M} \\
\text { Conv } \\
N=352\end{array}$ & $\begin{array}{l}\text { Student-student interactions (S-S } \\
\text { Count) and student-system } \\
\text { interactions (S-Sys Time) } \\
\text { positively affect GPA coded as LP } \\
(1,2) \text {; student-instructor } \\
\text { interactions (S-I Time) and student- } \\
\text { content frequency (S-C count) } \\
\text { negatively impact GPA }(3,4) .\end{array}$ & $\begin{array}{l}\text { (1) S-S Count } \Rightarrow \text { LP: } \\
0.30^{* * *} \\
\text { (2) S-Sys Time } \Rightarrow \text { LP: } \\
0.12^{*} \\
\text { (3) S-I Time } \Rightarrow \text { LP: } \\
0.15^{* *} \\
\text { (4) S-C Count } \Rightarrow \text { LP: } \\
0.14^{* *}\end{array}$ & $\begin{array}{l}0.148 \\
0.07 \\
-0.075 \\
-0.06\end{array}$ & $\begin{array}{l}\mathrm{A} \\
\mathrm{MC} \\
\mathrm{A} \\
\mathrm{C}\end{array}$ \\
\hline $\begin{array}{l}\text { Adamopoulo } \\
\text { s, } 2013\end{array}$ & $\begin{array}{l}\text { ON } \\
\text { (MOOC) } \\
\text { USA }\end{array}$ & $\begin{array}{l}\text { Resources, } \\
\text { supports, } \\
\text { tasks: } \\
\text { design } \\
\text { validation }\end{array}$ & $\begin{array}{l}\text { Demographics; } \\
\text { discussion post } \\
\text { sentiments; } \\
\text { course } \\
\text { materials; } \\
\text { workload } \\
\text { estimate; } \\
\text { course } \\
\text { progress; } \\
\text { difficulty; self- } \\
\text { reported } \\
\text { progress; drop- } \\
\text { out }\end{array}$ & $\begin{array}{l}\mathrm{L} \\
\operatorname{Ran} \\
N= \\
1,043\end{array}$ & $\begin{array}{l}\text { Teacher presence (1) positively } \\
\text { affects MOOC retention coded as } \\
\text { CO. Sentiments in discussion } \\
\text { forums affect completion }(2) ; \\
\text { course difficulty }(3) \text {, self-paced (4), } \\
\text { and duration }>8 \text { weeks }(5) \\
\text { negatively impact MOOC } \\
\text { retention. }\end{array}$ & $\begin{array}{l}\text { (1) Teacher presence } \Rightarrow \\
\text { CO: at least } 0.079 \\
\text { (2) Sentiments } \Rightarrow \text { CO: at } \\
\text { least } 0.102 * \\
\text { (3) Course difficulty } \Rightarrow \\
\text { CO: at least } 0.144 * * \\
\text { (4) Self-paced } \Rightarrow \text { CO: at } \\
\text { least } 0.144 * * \\
\text { (5) Duration } \Rightarrow \text { CO: at } \\
\text { least } 0.102 *\end{array}$ & $\begin{array}{l}0.040 \\
-0.051 \\
-0.072 \\
-0.072 \\
-0.051\end{array}$ & $\begin{array}{l}\mathrm{A} \\
\mathrm{A} \\
\mathrm{MC} \\
\mathrm{MC}\end{array}$ \\
\hline \multicolumn{9}{|c|}{ Coding for Ways of Learning — Personalization (Tailored Learning and Predictive Analytics) } \\
\hline $\begin{array}{l}\text { Dodge et al., } \\
2015\end{array}$ & $\begin{array}{l}\text { BL } \\
\text { USA }\end{array}$ & $\begin{array}{l}\text { Supports: } \\
\text { engagement }\end{array}$ & $\begin{array}{l}\text { LMS logins; } \\
\text { exam grades, } \\
\text { quiz scores; } \\
\text { clicker points } \\
\text { as proxy for } \\
\text { lecture } \\
\text { attendance }\end{array}$ & $\begin{array}{l}\mathrm{S}-\mathrm{L} \\
\operatorname{Exp} \\
N=882\end{array}$ & $\begin{array}{l}\text { Analytics-based email nudges } \\
\text { improve final grade (LP) for those } \\
\text { PSY/STATS students receiving at } \\
\text { least one trigger }(1,2) \text {. Pass rates } \\
\text { (coded as CO) improved for Pell- } \\
\text { eligible students (lower } \\
\text { socioeconomic status; } 3 \text { ) but not } \\
\text { overall. }\end{array}$ & $\begin{array}{l}\text { (1) Email (all) } \Rightarrow \text { LP } \\
\text { (PSY): } 2.787 * * * \\
\text { (2) Email (all) } \Rightarrow \text { LP } \\
\text { (STATS): } 1.922 * * * \\
\text { (3) Email (PELL) } \Rightarrow \\
\text { CO: } 0.351 * * *\end{array}$ & $\begin{array}{l}0.812 \\
0.693 \\
0.173\end{array}$ & $\begin{array}{l}\mathrm{A} \\
\mathrm{A} \\
\mathrm{A}\end{array}$ \\
\hline $\begin{array}{l}\text { Tempelaar et } \\
\text { al., 2015) }\end{array}$ & $\begin{array}{l}\mathrm{BL} \\
\mathrm{NL}\end{array}$ & $\begin{array}{l}\text { Tasks, } \\
\text { resources, } \\
\text { supports: } \\
\text { cognition } \\
\text { performance }\end{array}$ & $\begin{array}{l}\text { Demographics; } \\
\text { diagnostic test } \\
\text { scores; learning } \\
\text { disposition data } \\
\text { (Likert scale); } \\
\text { LMS logs; e- } \\
\text { tutorial scores } \\
\text { (quizzes, } \\
\text { practice, } \\
\text { formative); } \\
\text { final exam } \\
\text { mark }\end{array}$ & $\begin{array}{l}\mathrm{L} \\
\text { Conv } \\
N=873\end{array}$ & $\begin{array}{l}\text { Cognitive variables (COG) predict } \\
\text { overall student learning } \\
\text { performance LP (1). Formative } \\
\text { assessment (FA) and learning } \\
\text { emotions (EM) have higher impact } \\
\text { on LP }(2,3) \text { versus LMS usage (4). }\end{array}$ & $\begin{array}{l}\text { (1) } \mathrm{COG} \Rightarrow \operatorname{LP} 1.328^{\mathrm{a}} \\
\text { (2) } \mathrm{EM} \Rightarrow \operatorname{LP} 1.074^{\mathrm{a}} \\
\text { (3) } \mathrm{FA} \Rightarrow \operatorname{LP} 1.131^{\mathrm{a}} \\
\text { (4) } \mathrm{LMS} \Rightarrow \operatorname{LP} 0.374^{\mathrm{a}}\end{array}$ & $\begin{array}{l}0.799 \\
0.473 \\
0.497 \\
0.184\end{array}$ & $\begin{array}{l}\mathrm{C} \\
\mathrm{A} \\
\mathrm{C} \\
\mathrm{C}\end{array}$ \\
\hline
\end{tabular}


JOURNAL OF LEARNING ANALYTICS

\begin{tabular}{|c|c|c|c|c|c|c|c|c|}
\hline $\begin{array}{l}\text { Tabuenca et } \\
\text { al., } 2015\end{array}$ & $\begin{array}{l}\mathrm{ON} \\
\mathrm{NL}\end{array}$ & $\begin{array}{l}\text { Supports: } \\
\text { self- } \\
\text { regulation }\end{array}$ & $\begin{array}{l}\text { Learn Tracker } \\
\text { app recordings; } \\
\text { web log data } \\
\text { (subject, time } \\
\text { stamp, duration } \\
\text { of activity); } \\
\text { Likert scales }\end{array}$ & $\begin{array}{l}\mathrm{S} \\
\text { Conv } \\
N=36\end{array}$ & $\begin{array}{l}\text { Time management }(\mathrm{TM}) \text { improves } \\
\text { over time }(1 ; p=0.06), \text { affecting } \\
\text { self-regulated learning processes } \\
(\mathrm{OP}, 2) . \text { Effectiveness of email } \\
\text { messages to students depends on } \\
\text { timing (3) and content }(4) .\end{array}$ & $\begin{array}{l}\text { (1) Time } \Rightarrow \text { TM (start vs } \\
\text { week } 16 \text { ): } 0.537 \\
\text { (2) TM strategies } \Rightarrow \text { OP } \\
\text { (wk 8): }-0.882^{*} \\
\text { (3) TM Message } \\
\text { Morning } \Rightarrow \text { OP: } 1.129 * \\
\text { (4) TM Message content } \\
\text { week } 4 \Rightarrow \text { OP: }-0.730^{*} \\
\text { (5) TM Message content } \\
\text { week } 8:-0.882^{*} * \\
\text { Note. Neg. values } \\
\text { reversed for Fig } 3 \\
\text { (planned contrasts). }\end{array}$ & $\begin{array}{l}0.259 \\
-0.404 \\
0.491 \\
-0.343 \\
-0.404\end{array}$ & $\begin{array}{l}\mathrm{NS} \\
\mathrm{MC} \\
\mathrm{MC} \\
\mathrm{MC} \\
\mathrm{MC}\end{array}$ \\
\hline $\begin{array}{l}\text { Ott et al., } \\
2015\end{array}$ & $\begin{array}{l}\text { F2F } \\
\text { NZ }\end{array}$ & $\begin{array}{l}\text { Supports: } \\
\text { self- } \\
\text { regulation }\end{array}$ & $\begin{array}{l}\text { Pre-course } \\
\text { grade, } \\
\text { submission } \\
\text { time, } \\
\text { completion of } \\
\text { tasks and labs; } \\
\text { mid-semester } \\
\text { score; final } \\
\text { exam score }\end{array}$ & $\begin{array}{l}\mathrm{M} \\
\operatorname{Exp} \\
N=512\end{array}$ & $\begin{array}{l}\text { Infographics had no impact on } \\
\text { exam marks (LP) or course } \\
\text { outcome (CO) overall. Decreased } \\
\text { submission of programming lab } \\
\text { reports in high achiever group } \\
\text { (confidence building). }\end{array}$ & $\begin{array}{l}\text { Infographics } \Rightarrow \text { LP: no } \\
\text { effect } \\
\text { Infographics } \Rightarrow \text { CO: no } \\
\text { effect } \\
\text { Infographics (high } \\
\text { achievers) } \Rightarrow \\
\text { submission: } 0.49\end{array}$ & $\begin{array}{l}0 \\
0 \\
0.238\end{array}$ & $\begin{array}{l}\mathrm{A} \\
\mathrm{A} \\
\mathrm{NS}\end{array}$ \\
\hline $\begin{array}{l}\text { Gasević et } \\
\text { al., } 2016\end{array}$ & $\begin{array}{l}\text { BL } \\
\text { AUS }\end{array}$ & $\begin{array}{l}\text { Resources: } \\
\text { design } \\
\text { validation }\end{array}$ & $\begin{array}{l}\text { Moodle trace } \\
\text { data; student } \\
\text { data, grades, } \\
\text { demographics }\end{array}$ & $\begin{array}{l}\mathrm{L} \\
\text { Conv } \\
N=4134\end{array}$ & $\begin{array}{l}\text { Course login (1) and resource } \\
\text { access (2) impact positively on } \\
\text { grades (LP). Odds of failing (CO) } \\
\text { improve by } 1.4 \% \text { for additional } \\
\text { logins (3) and } 0.5 \% \text { for resource } \\
\text { access (4). Course design and LMS } \\
\text { activity associate with marks (LP) } \\
(5,6) .\end{array}$ & $\begin{array}{l}\text { (1) Course login } \Rightarrow \text { LP: } \\
0.409 * * * \\
\text { (2) Resources } \Rightarrow \text { LP } \\
: 0.227 * * * \\
\text { (3) Additional logins } \Rightarrow \\
\text { CO: }-0.244^{* * *} \\
\text { (4) Additional access } \Rightarrow \\
\text { CO: }-0.0761^{*} \\
\text { (5) Course design }{ }^{\mathrm{b}} \Rightarrow \\
\text { LP: } 0.096^{* * *} \\
\text { (6) LMS activity } \Rightarrow \text { LP: } \\
0.0481 * * *\end{array}$ & $\begin{array}{l}0.200 \\
0.113 \\
-0.121 \\
-0.038 \\
0.048 \\
0.048\end{array}$ & $\begin{array}{l}\mathrm{C} \\
\mathrm{C} \\
\mathrm{C} \\
\mathrm{C} \\
\mathrm{C} \\
\mathrm{C}\end{array}$ \\
\hline $\begin{array}{l}\text { Corrigan et } \\
\text { al, } 2015\end{array}$ & $\begin{array}{l}\text { F2F } \\
\text { IRELAND }\end{array}$ & $\begin{array}{l}\text { Supports: } \\
\text { engagement }\end{array}$ & $\begin{array}{l}\text { Moodle trace } \\
\text { data; grades }\end{array}$ & $\begin{array}{l}\mathrm{M}-\mathrm{L} \\
\text { Conv } \\
N=1181\end{array}$ & $\begin{array}{l}\text { Analytics-based emails to students } \\
\text { (weighted by opt-in, i.e., } 75 \% \text { of } \\
\text { enrolled students) improved final } \\
\text { grade by } 2.67 \% \text {. }\end{array}$ & $\begin{array}{l}\text { For all significant } \\
\text { improvements } \\
\text { Email nudges } \Rightarrow \text { LP: } \geq \\
0.096^{*}\end{array}$ & $\geq 0.048$ & A \\
\hline $\begin{array}{l}\text { Milliron et } \\
\text { al., } 2014\end{array}$ & $\begin{array}{l}\text { BL, ON } \\
\text { USA }\end{array}$ & $\begin{array}{l}\text { Supports: } \\
\text { persistence } \\
\text { retention }\end{array}$ & $\begin{array}{l}\text { Student } \\
\text { information; } \\
\text { LMS activity; } \\
\text { GPA; credits } \\
\text { earned as proxy } \\
\text { for engagement } \\
\text { (Civitas Inspire } \\
\text { score) }\end{array}$ & $\begin{array}{l}\mathrm{L} \\
\operatorname{Exp} \\
N>5000\end{array}$ & $\begin{array}{l}\text { Emails based on identified risk of } \\
\text { failing plus advisors improve } \\
\text { course completion (CO) for a test } \\
\text { sub-group (1). Emails aimed at } \\
\text { disengaged students improve } \\
\text { overall persistence/re-enrollment } \\
\text { by } 3 \%(2) \text {. Analytics-based emails } \\
\text { increase persistence rate (retention, } \\
\text { CO) for new compared to advanced } \\
\text { students (3). }\end{array}$ & $\begin{array}{l}\text { (1) Email plus advisor } \\
\Rightarrow \text { CO: } 0.047 \\
\text { (2) Email } \Rightarrow \text { CO: } 0.013 \\
\text { (3) Email by student } \\
\text { group } \Rightarrow \text { CO: } 0.041\end{array}$ & $\begin{array}{l}0.023 \\
0.006 \\
0.021\end{array}$ & $\begin{array}{l}\mathrm{A} \\
\mathrm{A} \\
\mathrm{A}\end{array}$ \\
\hline
\end{tabular}

$\mathrm{ON}=$ online delivery; $\mathrm{BL}=$ blended learning; $\mathrm{F} 2 \mathrm{~F}=$ in person delivery

$\mathrm{S}=$ small sample $(n<100) ; \mathrm{M}=$ medium $(n=100-250) ; \mathrm{L}=$ large $(n>250)$; Conv = convenience (purposive) sampling;

Rand = randomized; Exp = experimental design with a clear control group; adapted from Cheung and Slavin (2016).

Range of $p$-values as reported by the authors of each respective study: ${ }^{*} p<0.05 .{ }^{*} p<0.01 .{ }^{* * *} p<0.001$

${ }^{a} p$-value not reported by authors.

${ }^{\mathrm{b}}$ Cohen's $d$ for any differences in percent mark between courses (calculated based on the reported $p$-value).

\section{Codes:}

C: cognitive; MC: metacognitive; SC: sociocommunicative; A: affective; NS: not shown in Forest plot

LP: learning performance such as GPA, grade, final exam, scores, final grade, course achievement

CO: course outcome such as pass/fail, persistence (re-enrollment), completion, retention

OP: online presence such as cognitive presence, online behaviour changes, group leadership effectiveness, cognitive processes where no measures were given for learning performance and course outcome 
Table S4. Characteristics and Extracted Effects with Recalculated Cohen's $d$ and Pearson $r$ for 13 Selected Studies Identified in Phase Two of review

\begin{tabular}{|c|c|c|c|c|c|c|c|c|}
\hline Authors & $\begin{array}{l}\text { Setting } \\
\text { Country }\end{array}$ & Objectives & LA Data & $\begin{array}{l}\text { Study } \\
\text { Design }\end{array}$ & $\begin{array}{l}\text { Main } \\
\text { findings }\end{array}$ & $\begin{array}{l}\text { Effect sizes } \\
(\text { Cohen's } d)\end{array}$ & $r$ & $\begin{array}{l}\text { Implications or } \\
\text { recommendations for } \mathrm{LD}\end{array}$ \\
\hline \multicolumn{9}{|c|}{ Collaboration (social learning and collective efficacy) } \\
\hline $\begin{array}{l}\text { Akhtar, } \\
\text { Warburton, } \\
\& \mathrm{Xu}, 2017\end{array}$ & $\begin{array}{l}\text { BL } \\
\text { UK } \\
\text { CAD } \\
\text { Design }\end{array}$ & $\begin{array}{l}\text { To identify, } \\
\text { measure critical } \\
\text { factors } \\
\text { influencing } \\
\text { outcomes in } \\
\text { lab-based } \\
\text { teaching for the } \\
\text { prediction of } \\
\text { student } \\
\text { outcomes }\end{array}$ & $\begin{array}{l}\text { CAD design } \\
\text { marks; log } \\
\text { data; } \\
\text { attendance; } \\
\text { learner } \\
\text { distance from } \\
\text { lecturer; } \\
\text { student } \\
\text { grouping } \\
\text { patterns in } \\
\text { lab }\end{array}$ & $\begin{array}{l}\mathrm{L} \\
\text { Conv } \\
N=331\end{array}$ & $\begin{array}{l}\text { Sitting in groups had a } \\
\text { significant impact on CAD } \\
\text { design marks (LP), } \\
\text { whereas distance from the } \\
\text { lecturer's workstation } \\
\text { negatively affected mark. }\end{array}$ & $\begin{array}{l}\text { Lab attendance } \Rightarrow \\
\text { LP } \\
d=0.49 \\
\text { Seating group } \Rightarrow \\
\text { LP } \\
d=0.51 \\
\text { Distance to } \\
\text { lecturer } \Rightarrow \text { LP } \\
d=-0.24\end{array}$ & $\begin{array}{l}0.24^{* *} \\
* \\
0.25^{* *} \\
-0.12 *\end{array}$ & $\begin{array}{l}\text { Rearranging seating } \\
\text { configurations in lab-based } \\
\text { teaching can improve } \\
\text { student performance. Focus } \\
\text { group interviews confirmed } \\
\text { students' importance of } \\
\text { attending F2F labs. }\end{array}$ \\
\hline $\begin{array}{l}\text { Nguyen, } \\
\text { Rienties, } \\
\text { Toetenel, } \\
\text { Ferguson, \& } \\
\text { Whitelock, } \\
2017 \\
\text { (extended } \\
\text { analysis of } \\
\text { Rienties \& } \\
\text { Toetenel, } \\
\text { 2016) }\end{array}$ & $\begin{array}{l}\mathrm{ON} \\
\mathrm{UK} \\
\mathrm{UG}\end{array}$ & $\begin{array}{l}\text { To investigate } \\
\text { the effect of LD } \\
\text { in computer- } \\
\text { based } \\
\text { assessment } \\
\text { (CBA) on pass } \\
\text { rates and } \\
\text { engagement }\end{array}$ & $\begin{array}{l}\text { LD activity } \\
\text { categories, } \\
\text { VLE } \\
\text { engagement } \\
\text { indicators }\end{array}$ & $\begin{array}{l}\text { L } \\
\text { Conv } \\
N=74 \\
\text { modules } \\
N>72 \mathrm{~K} \\
\text { students }\end{array}$ & $\begin{array}{l}\text { All LD activities explained } \\
\text { up to } 58 \% \text { of the } \\
\text { variability in student VLE } \\
\text { engagement controlled for } \\
\text { differences in modules. } \\
\text { CBA assessment } \\
\text { significantly predicted } \\
\text { pass rates. Communication } \\
\text { and interaction activities } \\
\text { were significantly } \\
\text { associated with VLE } \\
\text { engagement per week } \\
\text { within and across } \\
\text { modules. }\end{array}$ & $\begin{array}{l}\text { All LD activities } \\
\Rightarrow \text { VLE }(\mathrm{OP}) d= \\
2.34 \\
\text { CBA } \Rightarrow \text { pass rates } \\
(\mathrm{CO}) \\
d=0.70 \\
\text { Assessment } \\
\text { activities } \Rightarrow \text { VLE } \\
(\mathrm{OP}) d=0.41 \\
\text { Communication } \\
\text { activities } \Rightarrow \text { VLE } \\
\text { (OP) } d=0.56 \\
\text { Interactive } \\
\text { activities } \Rightarrow \text { VLE } \\
(\mathrm{OP}) d=0.32\end{array}$ & $\begin{array}{l}0.76^{* *} \\
0.33^{*} \\
0.20^{* *} \\
0.27^{* *} \\
0.16^{* *}\end{array}$ & $\begin{array}{l}\text { Assessment as learning is } \\
\text { diverse in terms of types } \\
\text { and approaches, which } \\
\text { needs to be taken into } \\
\text { consideration when } \\
\text { designing for LA. } \\
\text { Activities where students } \\
\text { share, debate, discuss } \\
\text { (communication) } \\
\text { encourage VLE } \\
\text { engagement. }\end{array}$ \\
\hline $\begin{array}{l}\text { Rienties \& } \\
\text { Toetenel, } \\
2016\end{array}$ & $\begin{array}{l}\mathrm{ON} \\
\mathrm{UK} \\
\mathrm{UG}\end{array}$ & $\begin{array}{l}\text { To link LD } \\
\text { with student } \\
\text { engagement, } \\
\text { satisfaction and } \\
\text { retention }\end{array}$ & $\begin{array}{l}\text { LD } \\
\text { categories, } \\
\text { time spent on } \\
\text { VLE; time } \\
\text { spent per } \\
\text { VLE session }\end{array}$ & $\begin{array}{l}\mathrm{L} \\
\text { Conv } \\
N=151 \\
\text { modules } \\
N> \\
110 \mathrm{~K} \\
\text { students } \\
\text { Conv }\end{array}$ & $\begin{array}{l}\text { Type of LD activities } \\
\text { strongly influenced } \\
\text { academic retention, with } \\
\text { communication activities } \\
\text { being the primary } \\
\text { predictor of pass rates. }\end{array}$ & $\begin{array}{l}\text { Assimilative LD } \\
\Rightarrow \mathrm{CO} \\
d=-0.56 \\
\text { Communication } \\
\Rightarrow \mathrm{CO} \\
d=0.56\end{array}$ & $\begin{array}{l}-0.27^{*} \\
* \\
0.27 * *\end{array}$ & $\begin{array}{l}\text { Assimilative activities and } \\
\text { fewer student-centred } \\
\text { approaches received } \\
\text { significantly higher } \\
\text { evaluation scores but had } \\
\text { no correlation to retention. } \\
\text { In online learning, the } \\
\text { focus needs to shift to } \\
\text { social learning away from } \\
\text { cognitive learning (often } \\
\text { used). }\end{array}$ \\
\hline \multicolumn{9}{|c|}{ Independent Learners (Self-Regulation and Real-Life Learning) } \\
\hline $\begin{array}{l}\text { Jovanović, } \\
\text { Dawson, } \\
\text { Gašević, } \\
\text { Whitelock- } \\
\text { Wainwright, } \\
\text { \& Pardo, } \\
2019\end{array}$ & $\begin{array}{l}\text { BL } \\
\text { AUS } \\
\text { UG/Eng }\end{array}$ & $\begin{array}{l}\text { To explore the } \\
\text { provision of a } \\
2 \mathrm{D} \text { tool to self- } \\
\text { report on } \\
\text { perceived } \\
\text { difficulty } \\
\text { (cognitive load) } \\
\text { and perceived } \\
\text { self-efficacy } \\
\text { (confidence to } \\
\text { do well) on } \\
\text { learning } \\
\text { performance } \\
\text { indicators }\end{array}$ & $\begin{array}{l}\text { Difficulty } \\
\text { score; self- } \\
\text { efficacy } \\
\text { score; final } \\
\text { mark; } \\
\text { timeliness }\end{array}$ & $\begin{array}{l}\mathrm{L} \\
\text { Conv } \\
N=488 \\
+N= \\
593\end{array}$ & $\begin{array}{l}\text { Timeliness of a student's } \\
\text { first access to a learning } \\
\text { activity was positively } \\
\text { associated with the } \\
\text { perceived effect on } \\
\text { students' self-efficacy but } \\
\text { with a small effect. Other } \\
\text { factors indicative of time } \\
\text { management as important } \\
\text { self-regulation skills } \\
\text { played a bigger role. }\end{array}$ & $\begin{array}{l}\text { Timeliness of first } \\
\text { access to a task } \Rightarrow \\
\text { Self-efficacy } \\
\text { (OP) } \\
d=0.09 \\
\text { Increase in self- } \\
\text { efficacy } \Rightarrow \text { LP } \\
d=0.24 \\
\text { Perceived } \\
\text { difficulty } \Rightarrow \text { LP } \\
d=0.29 \\
\text { Self-evaluation } \\
\text { activity (2D tool) } \\
\Rightarrow \text { LP } \\
d=0.64\end{array}$ & $\begin{array}{l}0.12 * * \\
* \\
0.14 * * \\
* \\
0.31 * * \\
*\end{array}$ & $\begin{array}{l}\text { The provision of a } \\
\text { personalized learning } \\
\text { toolkit (within Canvas) can } \\
\text { help with students' self- } \\
\text { reflection and evaluation of } \\
\text { their learning for improved } \\
\text { outcomes. BUT basing LA } \\
\text { on self-reports can suffer } \\
\text { from selection bias, e.g., } \\
\text { better performing students } \\
\text { engaged with it more. }\end{array}$ \\
\hline
\end{tabular}




\begin{tabular}{|c|c|c|c|c|c|c|c|c|}
\hline $\begin{array}{l}\text { Tempelaar, } \\
\text { Rienties, } \\
\text { Mittelmeier, } \\
\text { \& Nguyen, } \\
2018\end{array}$ & $\begin{array}{l}\text { BL } \\
\text { NL } \\
\text { UG } \\
\text { Math/Stats }\end{array}$ & $\begin{array}{l}\text { To characterize } \\
\text { groups of at- } \\
\text { risk students } \\
\text { based on } \\
\text { dispositional } \\
\text { data toward the } \\
\text { design of } \\
\text { educational } \\
\text { interventions } \\
\text { Note. } \\
\text { Extension from } \\
\text { Tempelaar et } \\
\text { al., } 2015 \text { (see } \\
\text { Table S3 this } \\
\text { review). }\end{array}$ & $\begin{array}{l}\text { Course } \\
\text { performance; } \\
\text { students' } \\
\text { dispositional } \\
\text { data (Likert } \\
\text { scales), e.g., } \\
\text { epistemic } \\
\text { emotions, } \\
\text { learning } \\
\text { styles, } \\
\text { attitudes } \\
\text { toward } \\
\text { learning, } \\
\text { motivation, } \\
\text { engagement, } \\
\text { self- } \\
\text { regulation, } \\
\text { goal setting }\end{array}$ & $\begin{array}{l}\mathrm{L} \\
\text { Conv } \\
N=1093\end{array}$ & $\begin{array}{l}\text { Learning behaviours } \\
\text { among different student } \\
\text { profiles based on mastery } \\
\text { in e-tutor can be explained } \\
\text { by differences in learning } \\
\text { dispositions; e.g., deep } \\
\text { learners showing strong } \\
\text { critical processing and } \\
\text { relating skills are less } \\
\text { inclined to rely on worked } \\
\text { examples in the math e- } \\
\text { tutor compared to surface } \\
\text { learners. Formative } \\
\text { assessment outcomes } \\
\text { constituted crucial } \\
\text { feedback to learners and } \\
\text { was prominent in LA- } \\
\text { based prediction. }\end{array}$ & $\begin{array}{l}\text { Student profile (e- } \\
\text { tutor mastery) } \Rightarrow \\
\text { Dispositions (OP) } \\
d \text { range: } 0.263 \text { to } \\
0.523 \\
\text { Student profile } \Rightarrow \\
\text { Quizzes and } \\
\text { exams (LP) } \\
d \text { range: } 0.60 \text { to } \\
1.1\end{array}$ & $\begin{array}{l}0.13 \text { to } \\
0.25 * * \\
* \\
0.29 \text { to } \\
0.48 * * \\
*\end{array}$ & $\begin{array}{l}\text { A combination of formative } \\
\text { feedback LA with } \\
\text { disposition data can } \\
\text { effectively inform } \\
\text { interventions and scaffold } \\
\text { students' ability to improve } \\
\text { self-regulation, goal } \\
\text { setting, and attainment of } \\
\text { positive epistemic } \\
\text { emotions. }\end{array}$ \\
\hline $\begin{array}{l}\text { Rubio et al, } \\
2018\end{array}$ & $\begin{array}{l}\text { BL/F2F } \\
\text { USA } \\
\text { UG } \\
\text { Spanish }\end{array}$ & $\begin{array}{l}\text { To investigate } \\
\text { the impact of } \\
\text { the BL } \\
\text { component on } \\
\text { teaching } \\
\text { presence and } \\
\text { student learning } \\
\text { behaviour and } \\
\text { achievement }\end{array}$ & $\begin{array}{l}\text { LMS logs } \\
\text { (page views, } \\
\text { participation, } \\
\text { on-time } \\
\text { submissions), } \\
\text { final grade, } \\
\text { teaching } \\
\text { presence } \\
\text { indicators } \\
\text { acc. to CoI } \\
\text { (Anderson et } \\
\text { al, 2001) }\end{array}$ & $\begin{array}{l}\mathrm{S} \\
\text { Conv } \\
N=78 \\
(\mathrm{BL}) \\
N=12 \\
(\mathrm{~F} 2 \mathrm{~F})\end{array}$ & $\begin{array}{l}\text { Continuity (active days } \\
\text { combined with on-time } \\
\text { submissions) impacts final } \\
\text { grade (LP), more so for } \\
\text { lower performing students } \\
\text { (Q1) compared to medium } \\
\text { and high performing } \\
\text { students (Q2-Q4). } \\
\text { Active (posting, quizzes, } \\
\text { updating assignments) and } \\
\text { passive (page views) } \\
\text { participation correlates } \\
\text { with final grade. }\end{array}$ & $\begin{array}{l}\text { Continuity (Q1- } \\
\text { Q4) } \Rightarrow \text { LP } \\
d=3.2 \\
\text { Continuity (Q1) } \\
\Rightarrow \text { LP } \\
d=2.49 \\
\text { Continuity (Q2- } \\
\text { Q4) } \Rightarrow \text { LP } \\
d=1.21 \\
\text { Active } \\
\text { participation (Q1- } \\
\text { Q4) } \Rightarrow \text { LP } \\
d=1.15 \\
\text { Passive } \\
\text { participation (Q1- } \\
\text { Q4) } \Rightarrow \text { LP } \\
d=1.38\end{array}$ & $\begin{array}{l}0.85^{*} \\
0.78^{*} \\
0.52 * \\
0.50^{*} \\
0.57^{*}\end{array}$ & $\begin{array}{l}\text { Recommendations for the } \\
\text { design of LA dashboards to } \\
\text { students for course success } \\
\text { included cut-off points: a } \\
\text { minimum of } 240 \text { min for } \\
\text { passive, and } 45 \text { min for } \\
\text { active participation was } \\
\text { correlated to successful } \\
\text { course outcome, plus a min } \\
\text { of } 50 \text { active days. Anything } \\
\text { below that resulted in lower } \\
\text { performance (Q1 students). }\end{array}$ \\
\hline $\begin{array}{l}\text { Pardo, Han, } \\
\text { \& Ellis, } 2017\end{array}$ & $\begin{array}{l}\text { ON } \\
\text { AUS } \\
\text { UG/Eng }\end{array}$ & $\begin{array}{l}\text { To investigate } \\
\text { the relations } \\
\text { between SRL, } \\
\text { interaction with } \\
\text { online learning } \\
\text { events, and } \\
\text { academic } \\
\text { performance }\end{array}$ & $\begin{array}{l}\text { Self- } \\
\text { regulated } \\
\text { learning } \\
\text { (SRL) scale, } \\
\text { LMS log } \\
\text { data, final } \\
\text { mark }\end{array}$ & $\begin{array}{l}\mathrm{M} \\
N=145\end{array}$ & $\begin{array}{l}\text { Among } 7 \text { SRL variables, } \\
\text { only test anxiety } \\
\text { significantly impacted } \\
\text { academic performance } \\
(7 \%) \text {. } \\
\text { Combination of SRL and } \\
\text { student engagement with } \\
\text { resources, and multiple- } \\
\text { choice questions in the } \\
\text { course notes explained } \\
32 \% \text { of the variation in } \\
\text { academic performance. } \\
\end{array}$ & $\begin{array}{l}\text { Test anxiety } \Rightarrow \\
\text { LP } \\
d=0.54 \\
\text { Test anxiety, } \\
\text { resources and } \\
\text { MCQs } \Rightarrow \text { LP } \\
d=1.35\end{array}$ & $\begin{array}{l}0.26^{*} \\
0.56^{*}\end{array}$ & $\begin{array}{l}\text { Reveal to students what } \\
\text { positive SRL involves, how } \\
\text { to interact effectively with } \\
\text { online learning. Pay } \\
\text { attention to negative } \\
\text { aspects of learning such as } \\
\text { test anxiety and address } \\
\text { poor engagement to } \\
\text { improve student outcomes. }\end{array}$ \\
\hline $\begin{array}{l}\text { Kim, Yoon, } \\
\text { Jo, \& Branch, } \\
2018\end{array}$ & $\begin{array}{l}\text { ON } \\
\text { KOREA } \\
\text { UG/Stats }\end{array}$ & $\begin{array}{l}\text { To investigate } \\
\text { learning } \\
\text { patterns in } \\
\text { students with } \\
\text { different SRL } \\
\text { profiles }\end{array}$ & $\begin{array}{l}\text { LMs log } \\
\text { data, MSQL } \\
\text { Likert scores, } \\
\text { course } \\
\text { achievement } \\
\text { (sum marks } \\
\text { and final } \\
\text { exam) }\end{array}$ & $\begin{array}{l}\mathrm{L} \\
\text { Conv } \\
N=284\end{array}$ & $\begin{array}{l}\text { Identification of } 3 \text { clusters: } \\
\text { self-regulated (SR), } \\
\text { partially SR (PSR), and } \\
\text { non-SR (NSR) students. } \\
\text { Differences in SRL } \\
\text { (clusters) impacts on } \\
\text { course achievement (LP). } \\
\text { LD proposed: For } \\
\text { asynchronous online } \\
\text { learning, LA approaches } \\
\text { need to include design } \\
\text { elements to provide } \\
\text { students with virtual } \\
\text { spaces to encourage help- } \\
\text { seeking behaviours (e.g., } \\
\text { CoIs) and metacognitive } \\
\text { feedback, e.g., intelligent } \\
\text { tutoring. }\end{array}$ & $\begin{array}{l}\text { Type of SR (SR, } \\
\text { PSR, NSR) } \Rightarrow \text { LP } \\
d=.89 \\
\text { Achievement in } \\
\text { SR cluster vs. } \\
\text { PSR } \\
d=0.55 \\
\text { achievement in } \\
\text { NSR cluster vs } \\
\text { PSR } \\
d=0.67\end{array}$ & $\begin{array}{l}0.41 * * \\
* \\
0.27 * * \\
* \\
-0.32 * \\
* *\end{array}$ & $\begin{array}{l}\text { Goal setting is an important } \\
\text { regulator of metacognitive } \\
\text { skills; study regularity and } \\
\text { help-seeking are crucial } \\
\text { indicators of SRL, with } \\
\text { time management highly } \\
\text { correlated with SR and } \\
\text { achievement, confirming } \\
\text { previous study by Jo et al. } \\
(2015) \text {. }\end{array}$ \\
\hline
\end{tabular}




\begin{tabular}{|c|c|c|c|c|}
\hline $\begin{array}{l}\text { Martin \& } \\
\text { Whitmer, } \\
2016\end{array}$ & $\begin{array}{l}\text { USA } \\
\text { ON } \\
\text { UG/Educ }\end{array}$ & $\begin{array}{l}\text { To investigate } \\
\text { effect of timed } \\
\text { adaptive release } \\
\text { of course } \\
\text { modules on } \\
\text { learning } \\
\text { behaviour and } \\
\text { LP }\end{array}$ & $\begin{array}{l}\text { LMS data } \\
\text { time spent } \\
\text { accessing } \\
\text { materials, } \\
\text { total items } \\
\text { accessed, } \\
\text { login } \\
\text { attempts }\end{array}$ & $\begin{array}{l}\mathrm{S} \\
\mathrm{EXP} \\
N=43\end{array}$ \\
\hline
\end{tabular}

Students in a timed

spent more time per

session than students in

the control.

Note. Unable to determine

impact on course grades

between the timed

adaptive and no timed

adaptive release treatments

due to skewed LP data $(<$

$\mathrm{B}+)$. adaptive release course

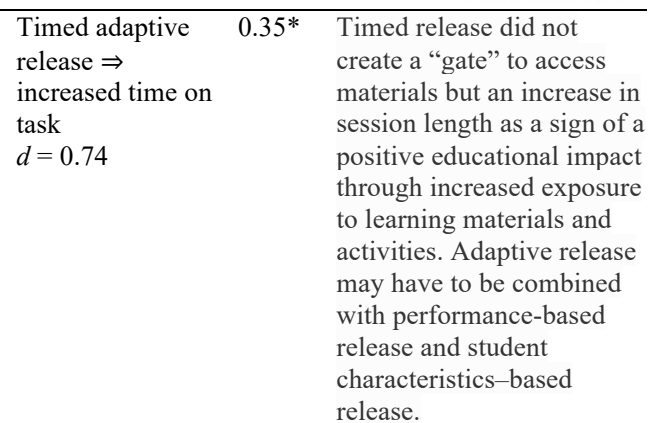

Personalization (Tailored Learning and Predictive Analytics)

Jovanović, AUS the effect of data, EXP provision of formative 3 personalized assessment cohorts:

task marks $\quad N=290$

$N=316$

student

$N=415$

satisfaction and

academic

achievement

\begin{tabular}{lllll}
\hline Zhang, Zou, & BL & To improve & LMS log & S \\
Miao, Zhang, & CHINA & students & data, & Exp \\
Hwang, \& & UG/Educ & enthusiasm, & questionnaire & $N=49$ \\
Zhu, 2019 & & performance, & s (self- & \\
& & achievements & efficacy, & \\
& & via & motivation, & \\
& & individualized & attitude to & \\
& & interventions & learn) &
\end{tabular}

Schumacher F2F?

$\begin{array}{lll}\text { To investigate } & \text { Likert scale } & \mathrm{L} \\ \text { the relationship } & \text { scores from } & \text { Conv } \\ \text { between } & \text { learning and } & N=802 \\ \text { motivational } & \text { achievement } & \text { across } \\ \text { dispositions } & \text { motivation, } & \text { program } \\ \text { and perceived } & \text { academic } & \text { and } \\ \text { support of } & \text { self-concept } & \text { subjects } \\ \text { learning } & \text { scale, } & \\ \text { analytics } & \text { expected LA } & \\ \text { systems (LA) } & \text { support } & \end{array}$

\& Ifenthaler, Germany the relationship scores from Cony

$2018 \quad$ UG/PG
The intervention $\quad$ Messages $\Rightarrow \quad 0.11^{* *}$ A learning design that

comprised personalized formative

messages to students using assessment

critical cut-off points for achievement (LP) $0.26^{*}$

each activity based on Cohen's $d=0.23$

engagement behaviour and Messages $\Rightarrow$

academic performance in student

satisfaction (OP)

$\begin{array}{ll}\text { formative tasks. } & d=0.55\end{array}$

impacted on the student (average) includes timely and critical points for data capture

related to student engagement and formative feedback can inform personalized and targeted feedback and also provides a connection point for instructors with their students in BL settings.

rate).

Students receiving $\quad$ Intervention $\Rightarrow \quad 0.30^{*} \quad$ Intervention can address

individualized Attitude to learn

interventions (monthly Cohen's $d=0.63 \quad 0.58 * *$ personal learning needs in

detailed report on learning Intervention $\Rightarrow$

progression and attitudes) motivation to

displayed a higher level of learn (OP) $d=$

learning motivation,

1.37 dashboards for students

learning attitude, and selfefficacy than those who

were provided with

Intervention $\Rightarrow$

$0.63 * *$ with follow-up by teachers

undifferentiated

interventions (monthly

report on the class

averages, no personal

self-efficacy (OP)

$*$

$d=1.63$

Intervention $\Rightarrow \quad 0.28^{*}$

active learning

behaviour (OP) $d$

$=1.4$

data). Overall

Intervention $\Rightarrow$

improvement in students' final mark (LP)

enthusiasm in learning and $d=0.59$

small effect on

performance.

Students' learning goal Learning goal

and performance-approach orientation $\Rightarrow$

goal orientation perceived LA

significantly predicted the support $d=0.53$

perceived support from Performance-

approach goal

orientation $\Rightarrow$

learning analytics (delt

Surprisingly, students with perceived LA
criterion-based and social

reference norm did not $\quad 0.44$

perceive benefits from LA. No individual,

Note. No actual LA were goal, criterion

implemented; perceived based academic

benefits data were

self-concept $\Rightarrow$

captured via questionnaire

perceived LA

only.

\section{$0.26^{* *}$ For the design of effective personalized learning, appropriate indicators and data sources considering \\ $0.21 * *$ students' motivational dispositions need to be \\ $-0.22 *$ included in the design of LA interventions to be of perceived benefit.}

$d=-0.45$

With individual,

goal, criterion

based academic

self-concept $\Rightarrow$

perceived LA

support $d=0.33$ 




$\mathrm{ON}=$ online delivery; $\mathrm{BL}=$ blended learning; $\mathrm{F} 2 \mathrm{~F}=$ in person delivery

$\mathrm{S}=$ small sample $(n<100) ; \mathrm{M}=$ medium $(n=100-250) ; \mathrm{L}=$ large $(n>250)$; Conv = convenience (purposive) sampling; Rand $=$ randomized; Exp = experimental design with a clear control group; adapted from Cheung and Slavin (2016).

Range of $p$-values as reported by the authors of each respective study: ${ }^{*} p<0.05 .{ }^{* *} p<0.01 .{ }^{* * *} p<0.001$

\section{Codes:}

LP: learning performance such as GPA, grade, final exam, scores, final grade, course achievement

CO: course outcome such as pass/fail, persistence (re-enrollment), completion, retention

OP: online presence such as cognitive presence, online behaviour changes, group leadership effectiveness, cognitive processes where no measures were given for learning performance and course outcome

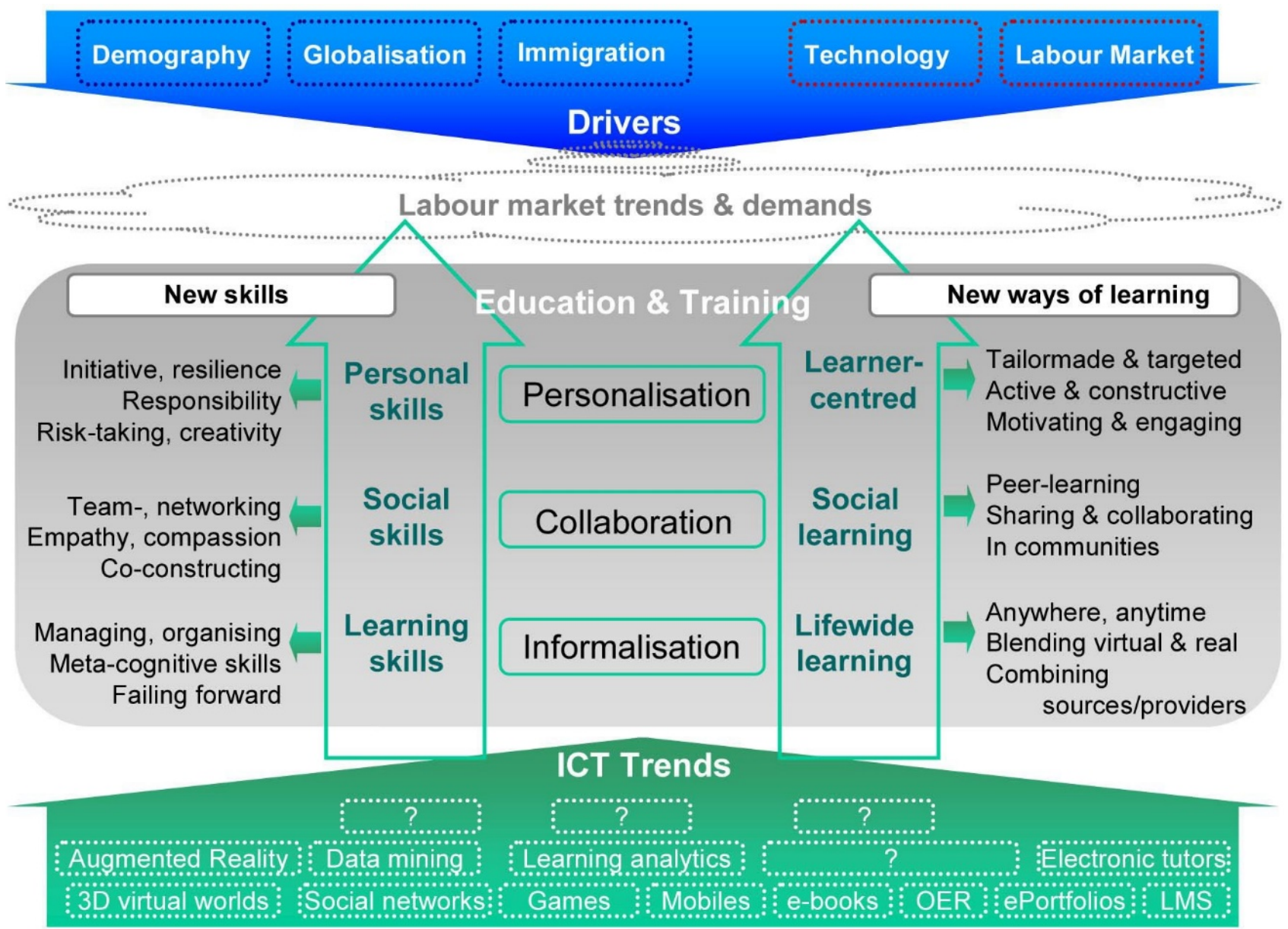

Figure S1. Original map of the future of learning proposed by Redecker et al., 2011 